\title{
The Trade Effect of Border Controls: Evidence from the European Schengen Agreement ${ }^{*}$
}

\author{
Gabriel FELBERMAYR ${ }^{\dagger}$ \\ Jasmin GRÖSCHL \\ Thomas STEINWACHS ${ }^{\S}$
}

Ifo Institute

March 2017

\begin{abstract}
The Schengen Agreement is an important milestone in the European integration process. The purpose is to facilitate the flow of goods, services, and persons across intraEuropean borders. How successful is it in achieving this goal? We apply an econometric gravity analysis to bilateral trade. Unlike earlier analysis, we acknowledge that Schengen treats different country pairs differently, depending on their relative geographical location. Moreover, we find it crucial to carefully control for other elements of European integration such as membership in the customs union, the single market or the currency union, and to factor in countries' trade with themselves. Schengen has boosted trade by about $2.81 \%$ on average, on top of the EU's trade effects (equivalent to a drop in tariffs between 0.46 and 1.02 percentage points). Trade creation effects for services are stronger than for goods, but estimates feature larger parameter uncertainty. Peripheral countries benefit more than central ones. Other aspects of EU integration matter much more for trade than Schengen.
\end{abstract}

Keywords: Trade Integration, European Integration, Schengen Agreement, Gravity

JEL-Classification: F10, F15, N74, N94

\footnotetext{
${ }^{*}$ We thank H.-W. Sinn, Y. Yotov, and J. Zettelmeyer and seminar participants in Munich, Vienna and Yogyakarta for comments and suggestions.

$\dagger$ Ifo Institute - Leibniz Institute for Economic Research at the University of Munich, Poschingerstr.5, 81679

Munich, Germany; LMU, CESifo \& GEP; felbermayr@ifo.de

¥ Ifo Institute - Poschingerstr.5, 81679 Munich, Germany; CESifo; groeschl@ifo.de

$\S$ Ifo Institute - Poschingerstr.5, 81679 Munich, Germany; steinwachs@ifo.de
} 


\title{
The Trade Effects of Border Controls: Evidence from the European Schengen Agreement*
}

\author{
Gabriel Felbermayr ${ }^{\dagger}$ Jasmin Gröschl; and Thomas Steinwachs ${ }^{\S}$
}

March 17, 2017

\begin{abstract}
The Schengen Agreement is an important milestone in the European integration process. The purpose is to facilitate the flow of goods, services, and persons across intra-European borders. How successful is it in achieving this goal? We apply an econometric gravity analysis to bilateral trade. Unlike earlier analysis, we acknowledge that Schengen treats different country pairs differently, depending on their relative geographical location. Moreover, we find it crucial to carefully control for other elements of European integration such as membership in the customs union, the single market or the currency union, and to factor in countries' trade with themselves. Schengen has boosted trade by about $2.81 \%$ on average, on top of the EU's trade effects (equivalent to a drop in tariffs between 0.46 and 1.02 percentage points). Trade creation effects for services are stronger than for goods, but estimates feature larger parameter uncertainty. Peripheral countries benefit more than central ones. Other aspects of EU integration matter much more for trade than Schengen.
\end{abstract}

Keywords: Trade Integration, European Integration, Schengen Agreement, Gravity

JEL-Classification: F10, F15, N74, N94

${ }^{*}$ We thank H.-W. Sinn, Y. Yotov, and J. Zettelmeyer and seminar participants in Munich, Vienna and Yogyakarta for comments and suggestions.

${ }^{\dagger}$ Ifo Institute - Leibniz Institute for Economic Research at the University of Munich, Poschingerstr. 5, 81679 Munich, Germany; LMU, CESifo \& GEP; felbermayr@ifo.de

${ }_{\ddagger}^{\ddagger}$ Ifo Institute, Poschingerstr. 5, 81679 Munich, Germany; CESifo; groeschl@ifo.de

§Ifo Institute, Poschingerstr. 5, 81679 Munich, Germany; steinwachs@ifo.de 


\section{INTRODUCTION}

The Schengen Agreement is seen as an important milestone in the European integration process. In this paper, we test econometrically whether the agreement has indeed fulfilled the promises. More precisely, we ask whether Schengen has significantly spurred trade in goods and services amongst its members.

The agreement has abolished regular identity checks at internal EU borders, allowing them only in emergency situations and for limited periods of time. Schengen also sets out the modalities of cooperation in border-related police work. The agreement was signed in 1985 in the Luxembourg town of Schengen by Belgium, the Netherlands, Luxembourg, France, and Germany. In 1995, it was first enforced amongst seven countries (the above-mentioned five plus Spain and Portugal). The Schengen area has grown over time and today covers 26 countries. The EU members Bulgaria, Croatia, Cyprus, Ireland, Romania and the United Kingdom do not participate in Schengen while the non-EU countries Iceland, Norway, and Switzerland are part of it.

The Schengen Agreement is part and parcel of the complex European integration process. It complements the European customs union and single market, and the monetary union. By ending border controls, Schengen facilitates and accelerates the crossing of borders within Europe and delivers very tangible benefits for millions of travelers and commuters. Ademmer et al. (2015) argue that the reduction of waiting times at borders reduces trade costs, which should stimulate cross border exchange and the mobility of service providers as well as of consumers. ${ }^{1}$ Tighter regional integration should yield welfare benefits for citizens. Conversely, the reintroduction

\footnotetext{
${ }^{1}$ Clearly, trade gains are not the only motivation for Schengen or European integration more broadly (see Baldwin et al., 2008).
} 
of identity checks at internal Schengen borders as one consequence of the European refugee crisis of 2015 may jeopardize these gains. ${ }^{2}$ The goal of this paper is to estimate the trade-creating effects of Schengen in order to shed light on the size of the benefits at stake when ending the agreement as a whole. ${ }^{3}$

To this end, it is important to acknowledge a special characteristic of the Schengen Agreement. Unlike the customs union, the single market, Eurozone membership or other regional trade agreements (RTAs), which all have a clear bilateral scope, the Schengen Agreement has an obvious and important spatial dimension. Landborne trade flows between two countries in Europe may cross only one internal border (e.g., France - Germany) or up to eight of them (e.g., Portugal - Finland). Hence, Schengen membership treats country pairs heterogeneously, depending on the number of internal Schengen borders crossed. This feature is ignored in the small existing literature, which treats Schengen analogously to trade agreements and currency unions, e.g., Davis and Gift (2014) or Chen and Novy (2011).

Moreover, land-borne trade between two Schengen outsiders (e.g., Romania and the UK) or between Schengen outsiders and insiders (e.g., Turkey and Germany)

${ }^{2}$ Monar (2014) offers a discussion of the 'Regulation (EU) 1051/2013 on common rules for the temporary re-introduction of border control at internal borders in exceptional circumstances'. Trauner and Ripoll Servent (2016) argue that it is unclear whether the refugee crisis will strengthen or weaken the Schengen area in the long run.

${ }^{3}$ Our estimates imply long-run effects of undoing Schengen, assuming that check point conditions equivalent to the pre-Schengen era are re-established. Our data does not allow isolating the effects of temporary exemptions. Since the Agreement's implementation, border infrastructure and personnel have been built back whereas trade flows have grown considerably. Enforcing temporary exemptions where check-point conditions are worse than before Schengen suggests higher short-run effects than our long-run estimates suggest. 
can also benefit from the agreement as goods transit through Schengen space. ${ }^{4}$ We combine GIS data with information from Google Maps to count the number of Schengen borders crossed by truck (and ferry) along the shortest road distance between trading partners. This count variable is our measure of interest.

In contrast to existing studies, we do not exclude services trade or internal trade flows. We make progress by (i) using a more accurate definition of treatment, (ii) employing the most recent and most adequate data, and (iii) making full use of newest methodological advances, while strictly adhering to the predicaments of structural gravity theory as laid out in Head and Mayer (2014).

Our contribution is threefold: First, applying state-of-the art methods, we are able to provide an accurate partial equilibrium quantification of the trade (and trade cost) effects of Schengen. Flows of goods crossing a single Schengen border increase by $2.6 \%$ while services flows go up by $4.1 \%$ on average (equivalent to a drop in a tariff by 0.37 and 0.80 percentage points, respectively). Second, we consistently compare the trade effects of subsequent steps of European regional integration. Mutual EU membership increases trade in goods by $122.6 \%$ (53.2\% for the Customs Union and $69.4 \%$ for the Single Market) and in services by $39.8 \%$ for all countries that have joined the EU after 1995. Other RTAs established after 1995 boost trade by an additional $35.3 \%$ in goods and $20.2 \%$ in services. The common adoption of the Euro in addition to EU membership is again more important for goods trade $(15.3 \%)$ than for services trade (8.8\%). So, Schengen is comparatively less important. Third,

\footnotetext{
${ }^{4}$ Typically, econometric analysis of bilateral trade data assumes that third countries are affected only through general equilibrium effects by bilateral trade integration. Schengen is an example where third countries are directly affected through shorter transit times. We are grateful to a referee for pointing this out.
} 
exploiting its spatial dimension, we show that the trade cost effects of Schengen vary between 0.17 percentage points for Ireland to 0.83 percentage points for Estland, and that Schengen outsiders such as Turkey or Russia can benefit substantially (0.51 and 0.36 percentage points, respectively).

\section{EMPIRICAL MODEL}

Head and Mayer (2014) show that a broad class of general equilibrium trade models with constant elasticity of substitution aggregation gives rise to a gravity equation of the following form:

$$
X_{i j, t}^{s}=\frac{Y_{i, t}^{s} E_{j, t}^{s}}{Y_{t}^{s}} \cdot\left(1+\tau_{i j, t}^{s}\right)^{-\sigma^{s}}\left(\frac{\phi_{i j, t}^{s}}{\Omega_{i, t}^{s} \Omega_{j, t}^{s}}\right)^{1-\sigma^{s}}
$$

where $X_{i j, t}^{s}$ is the value of exports of country $i$ to country $j$ in sector $s$ at time $t$, $Y_{i, t}^{s}$ is country $i$ 's value of production in sector $s \in\{G, S, T\}$ for goods, services, and total trade, respectively. $E_{j, t}^{s}$ is country $j$ 's expenditure in sector $s, Y_{t}^{s}$ is the value of global output, $1+\tau_{i j, t}^{s}$ is an ad valorem tariff factor, $\phi_{i j, t}^{s} \geq 1$ measures bilateral non-tariff "iceberg" trade costs, and $\sigma^{s}>1$ is the sectoral elasticity of substitution. ${ }^{5}$ In the literature, $1-\sigma^{s}$ is often referred to as "the trade elasticity". The terms $\Omega_{i, t}^{s}$ and $\Omega_{j, t}^{s}$ are called "multilateral resistance" terms. They account

\footnotetext{
${ }^{5}$ Tariffs and non-tariff trade costs enter expression 1 with different exponents. The reason is that iceberg trade costs assume that $\phi_{i j, t}^{s} \geq 1$ units of a good must be produced in country $i$ for one unit to arrive for consumption in country $j$. The fraction $\phi_{i j, t}^{s}-1$ melts away in transit (Samuelson, 1954). Hence, in contrast to tariffs, higher non-tariff trade costs increase the physical quantity of goods to be shipped. This lowers (in absolute values) the elasticity of exports (price times quantity) with respect to $\phi_{i j, t}^{s}$ compared to the one with respect to $1+\tau_{i j, t}^{s}$.
} 
for the effects of third countries' trade costs on $i$ 's exporting and on $j$ 's importing behavior. These terms are generally unobserved and depend on bilateral trade costs between all trading partners worldwide.

Non-tariff trade costs $\phi_{i j, t}^{s}$ cannot be directly measured in the data but must be estimated. Suppressing sectoral indices to avoid cluttering, we follow common practice and specify

$$
\phi_{i j, t}=\prod_{\ell}\left(T_{i j, t}^{\ell}\right)^{\tilde{\delta}^{\ell}} \cdot \exp \left(\tilde{\beta} \text { Schengen }_{i j, t}+\sum_{k} \tilde{\alpha}^{k} Z_{i j, t}^{k}\right)
$$

where $T_{i j, t}^{\ell}$ denotes a trade cost shifter $\ell$ unrelated to policy (such as geographical or cultural distance). $Z_{i j, t}^{k}$ is an indicator variable capturing whether $i$ and $j$ are both taking part in an integration program $k$ (such as the customs union, the single market, the monetary union, or any other RTAs.

Substituting (2) into (1) and assuming that other trade costs $\mathbf{T}_{i j}^{s}$ are timeinvariant, we can write the estimation equation

$$
X_{i j, t}=\exp \left[\beta \text { Schengen }_{i j, t}-\sigma \ln \left(1+\tau_{i j, t}\right)+\sum_{k} \alpha^{k} Z_{i j, t}^{k}+\nu_{i j}+\nu_{i, t}+\nu_{j, t}\right]+\varepsilon_{i j, t}
$$

where $\beta \equiv(1-\sigma) \tilde{\beta}, \alpha^{k} \equiv(1-\sigma) \tilde{\alpha}^{k}$, and $\varepsilon_{i j, t}$ is a random disturbance. The terms $\nu_{i j}, \nu_{i, t}$, and $\nu_{j, t}$ are country-pair, and year specific importer and exporter fixed effects, respectively. Their presence implies that time-invariant country-pair specific determinants of sectoral trade flows drop out of the equation. Moreover, they fully control for all exporter- and importer-specific time-varying determinants of trade ( $\operatorname{such}$ as $Y_{i, t}, E_{j, t}, \Omega_{i, t}, \Omega_{j, t}$ ).

Except Russia and China, all countries in our sample are WTO members. Therefore, they apply the same tariff to all trade partners (most-favored nation principle, 
MFN), except in the case of a preferential trade agreement. Since we control for those explicitly, in principle, we could include the MFN tariff $t_{j, t}$ into the regression. We could identify $\sigma^{G}$ even in the presence of the $\nu_{j, t}$ fixed effects due to the presence of intranational trade (for which $\tau_{j, t}=0$ ); see Piermartini and Yotov (2016). In our regressions, we go one step further. We set $t_{i j, t}=\tau_{j, t} \times E X T R A_{i j}$, where $E X T R A_{i j}$ is a binary variable taking value 1 except if $j=i$ or when $i$ and $j$ are both part of the EU. This way, we identify $\sigma^{G}$ on the variance between intra- and international trade flows, and between EU and non-EU flows. As a side effect, this specification extracts the tariff-component of EU integration (the customs union effect), leaving the non-tariff component (the single market effect). We refrain from doing the same for other RTAs. ${ }^{6}$

The use of such a saturated model has several advantages. First, it provides some immunization against omitted variable bias as time-invariant bilateral or timedependent country-level factors affecting trade, which are not modeled by (1), are accounted for. Second, it frees us from approximating (or iteratively simulating) the multilateral resistance terms and from collecting sectoral output data (which are not always available in good quality). Third, the inclusion of bilateral fixed effects $\nu_{i j}$ is a defense against possible endogeneity concerns; see below.

We are interested in unbiased estimates of $\sigma, \alpha^{k}$ and, in particular, $\beta$. Contrary to the literature, we do not define Schengen $_{i j, t}$ as a binary variable taking value 1 if country $i$ and country $j$ have both ratified the Schengen Agreement. Such a definition mismeasures the treatment and misses systematic treatment heterogeneity:

\footnotetext{
${ }^{6}$ Clearly, the elasticity $\sigma^{s}$ can be estimated for goods trade only since services trade is not subject to any tariffs. It should not be overinterpreted, because its identification rests only on very few observations.
} 
A land-borne trade flow in Europe from $i$ to $j$ may cross one, two, or up to eight internal Schengen borders. ${ }^{7}$ Moreover, the pair ij may benefit from lower transit costs, even if $i$ and/or $j$ are outsiders to Schengen. Therefore, we use a count variable Schengen $_{i j, t}=\{1, \ldots, 8\}$ registering the number of Schengen border crossings that land-borne trade between $i$ and $j$ involves. ${ }^{8}$

The existing literature (e.g., Davis and Gift, 2014) is largely silent on the possibility that selection of country pairs into Schengen may not be random. The estimate of $\beta$ would be upward biased if trade shocks $\varepsilon_{i j, t}>0$ increase the odds of a trade route connecting $i$ and $j$ to be affected by Schengen. However, joining a plurilateral agreement such as Schengen is not a bilateral decision, and transportation costs between countries $i$ and $j$ depend on the Schengen status of transit countries. Thus, reverse causality may not be a major issue (for further treatment of potential endogeneity see the robustness section). Nonetheless, we include country-pair fixed effects $\nu_{i j}$ to account for all time-invariant determinants that might jointly affect Schengen $_{i j, t}$ and $X_{i j, t}$. This also addresses omitted variable bias and the endogeneity of other policy variables $Z_{i j, t}^{k}$, such as EU, Eurozone, or RTA membership, - controls that are crucial to identify an unconfounded treatment effect $\beta$ (see, e.g., Baier and Bergstrand, 2007).

It is important to acknowledge that the structural gravity equation (1) implies

${ }^{7}$ Evidence from France suggests that about three quarters of intra-European trade is landborne; see www.statistiques.developpementdurable.gouv.frntransportsn873.html.

${ }^{8}$ Rather than assuming linearity in the effect of Schengen borders, we could have specified an array of indicator variables, each taking the value of unity if one, two, three, ..., Schengen borders are crossed and zero else. However, it turns out that this strategy makes clean identification harder as we would have to estimate the effects of a further seven variables. 
that the analysis should not only include international trade but also intranational trade, for which $i=j$ (see, e.g., Anderson and Yotov, 2015). Inference based on international flows alone is likely to lead to biased estimates. Yotov (2012), Dai et al. (2014), and Bergstrand et al. (2015) prove the importance of this issue in theory and also document the quantitative relevance of including own trade in the ex post evaluation of trade policy.

We estimate equation (1) by Poisson Pseudo Maximum Likelihood (PPML) methods as recommended by Santos Silva and Tenreyro $(2006,2011)$ and Head and Mayer (2014). Standard errors allow for clustering at the country-pair level. Identification relies on the time variation within country pairs with different exposure to mutual EU, RTA, or EMU membership and the number of Schengen borders relative to the total number of borders crossed (the latter is captured by the bilateral fixed effect $\left.\nu_{i j}\right)$.

Before moving on, we briefly sketch expectations about the trade effects of Schengen. If border controls are abolished, waiting times and associated uncertainty are reduced such that international trade costs decline. Hence, we expect trade-creating effects of Schengen to be larger, the more Schengen borders a trade flow crosses. Other steps of European integration - customs union, single market, monetary union - target trade costs more directly, are more comprehensive, and therefore have more pronounced trade effects than Schengen. We expect to find a clear ranking of tradecreating effects. Moreover, the services sector is more strongly affected by Schengen than manufacturing, as easing the movement of people is a necessary precondition for many services to be provided. 


\section{DATA}

We use yearly bilateral data on goods and services trade flows between and within countries, and sectoral output and expenditure data from the World Input-Output Database (WIOD), described by Timmer et al. (2015). The data capture 40 countries and the years 1995 to 2011, giving us $40 \times 40 \times 17=27,200$ observations per sector. Geographical and historical variables stem from CEPII. Information on RTAs come from the WTO. ${ }^{9}$ MFN tariffs are taken from the World Integrated Trade Solutions (WITS-TRAINS) database.

Data on the successive accession of countries to the Schengen Agreement stem from the European Commission. ${ }^{10}$ We combine GIS data with information from Google Maps to count the number of Schengen borders crossed by truck (and ferry) moving from economic centers of $i$ to $j$ in year $t$.

From an econometric point of view, the often bemoaned variable geometry of Europe is an advantage. It allows us to use panel econometrics to disentangle the different trade effects of EU, Eurozone, and Schengen membership and of other trade agreements (e.g., EU-Turkey customs union, or pre-accession treaties). While all EMU countries are EU members and estimated EMU effects must therefore be interpreted as additional to EU effects, this relationship constitutes the only strict subset to consider. First, not all EU members belong to Schengen or the EMU. Second,

\footnotetext{
${ }^{9}$ The RTA gateway is accessible via http://rtais.wto.org/UI/PublicMaintainRTAHome.aspx.

${ }^{10}$ Starting with seven countries in 1995, the agreement was joined by Italy and Austria in 1997, Greece in 2000, Denmark, Finland, Iceland, Norway, and Sweden in 2001, the Czech Republic, Estonia, Hungary, Latvia, Lithuania, Malta, Poland, Slovakia, and Slovenia in 2007, Switzerland in 2008. The EU members Bulgaria, Croatia, Cyprus, Ireland, Romania and the United Kingdom do not participate in Schengen, while the non-EU countries Iceland, Norway, and Switzerland do.
} 
not all EMU members are part of Schengen and vice versa, and they have ratified the agreement at different times. Third, some Schengen countries are not part of the EU and, the way our Schengen variable is constructed, it directly affects also outsiders to both Schengen and the EU (e.g., Turkey and Russia). ${ }^{11}$ While variable geometry helps with separately identifying the trade effects of overlapping intergration steps, one caveat must be kept in mind: the effects are identified through country pairs switching status; e.g., the single market coefficient reflects the effects of new members joining the $\mathrm{EU}$ in the period of observation (e.g., the 10 middle and eastern European countries, plus Romania and Bulgaria.)

Since WIOD goes back exactly until 1995, the effects Schengen has on its founding members are absorbed by the country pair fixed effects, such that our estimates are driven exclusively by the 19 countries that have joined the Agreement over time. Similarly, our EU estimate is driven by those countries that have joined the EU after 1995. The same logic applies to the effects of RTAs that have entered into force before our period of investigation. The Euro became a real currency subject to a single monetary policy only in 1999 such that our EMU estimate fully captures the Euro effect.

Figure 1 shows how exports and imports of EU-27 countries are distributed across country-pairs involving the crossing of one to eight Schengen borders.

In 2011, 35\% of goods trade of EU-27 countries crosses one Schengen border. The shares are $17 \%, 7 \%$, and $3 \%$ for two, three or more than three borders, respectively. For services trade the shares are $21 \%, 13 \%, 7 \%$, and $3 \%$, respectively. The residual

\footnotetext{
${ }^{11}$ Note that our estimated Schengen effect can be interpreted individually even if non-EU Schengen countries are not included in WIOD.
} 


\section{Figure 1}

Total EU-27 Trade in bn. US Dollar along the Number of Schengen Borders Crossed, 2011
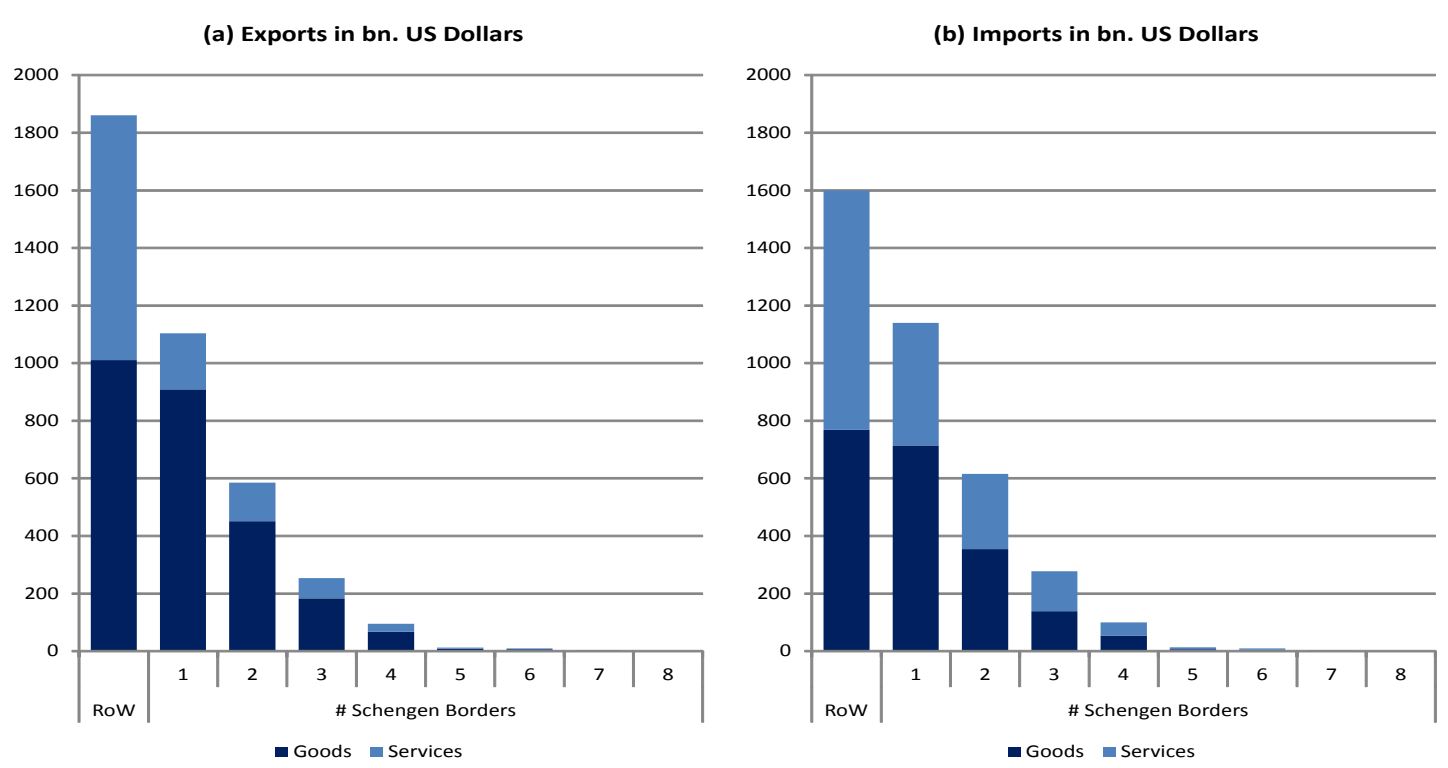

Note: Distribution of EU members' trade according to number of Schengen borders crossed in a bilateral relation. RoW denotes rest of the world.

originates from outside the EU-27. ${ }^{12}$ Extra-Schengen air-borne trade is unlikely to benefit from the Schengen Agreement; sea-borne trade, however, may well benefit, as goods are shipped from major seaports to consumers (see robustness checks).

\footnotetext{
${ }^{12}$ Note that RoW includes all trade beyond the 40 countries distinguished by WIOD. This comprises countries such as Norway, Switzerland, Iceland, and the Balkan, including Croatia. Gravity estimation results are thus slightly downward biased. Not considering RoW in calculating advalorem tariff equivalents would induce an upward bias. By including WIOD's RoW aggregate in ad-valorem tariff analysis, we opt for the more conservative approach given the null that Schengen does not affect trade flows.
} 


\section{BENCHMARK RESULTS}

Table 1 provides results for total, goods, and services trade. The regression models follow equation (1). They show that the effect of Schengen is substantially overestimated when failing to control for other elements of EU integration. Moreover, controlling for MFN tariffs in regressions for goods trade, we obtain an estimate of the tariff elasticity equal to -2.4. By construction, explicitly controlling for MFN tariffs only changes the effect of EU integration. Column (4) provides the effect of the EU inclusive of tariff elimination, column (5) exclusive of it. We can exploit this difference to separate the effects of the customs union from that of the single market.

\section{TABLE 1}

The Impact of Schengen on Bilateral Exports (1995 - 2011)

Dep. var.: Bilateral Exports

\begin{tabular}{|c|c|c|c|c|c|c|c|}
\hline & \multicolumn{2}{|c|}{ Total Trade } & \multicolumn{3}{|l|}{ Goods } & \multicolumn{2}{|l|}{ Services } \\
\hline & (1) & (2) & (3) & (4) & (5) & (6) & (7) \\
\hline Schengen & $\begin{array}{c}0.054^{* * *} \\
(0.01)\end{array}$ & $\begin{array}{c}0.0003 \\
(0.01)\end{array}$ & $\begin{array}{c}0.106^{* * *} \\
(0.02)\end{array}$ & $\begin{array}{c}0.026^{* * *} \\
(0.01)\end{array}$ & $\begin{array}{c}0.026^{* * *} \\
(0.01)\end{array}$ & $\begin{array}{c}0.067^{* * *} \\
(0.02)\end{array}$ & $\begin{array}{l}0.040^{*} \\
(0.02)\end{array}$ \\
\hline Both EU & & $\begin{array}{c}0.617^{* * *} \\
(0.07)\end{array}$ & & $\begin{array}{c}0.800^{* * *} \\
(0.07)\end{array}$ & $\begin{array}{c}0.527^{* * *} \\
(0.11)\end{array}$ & & $\begin{array}{c}0.335^{* * *} \\
(0.08)\end{array}$ \\
\hline Both Euro & & $\begin{array}{l}0.030 \\
(0.02)\end{array}$ & & $\begin{array}{c}0.137^{* * *} \\
(0.03)\end{array}$ & $\begin{array}{c}0.142^{* * *} \\
(0.03)\end{array}$ & & $\begin{array}{l}0.084^{*} \\
(0.04)\end{array}$ \\
\hline Other RTA & & $\begin{array}{c}0.250^{* * *} \\
(0.07)\end{array}$ & & $\begin{array}{c}0.294^{* * *} \\
(0.06)\end{array}$ & $\begin{array}{c}0.302 * * * \\
(0.07)\end{array}$ & & $\begin{array}{c}0.184^{* *} \\
(0.07)\end{array}$ \\
\hline Tariff & & & & & $\begin{array}{c}-2.443^{* * *} \\
(0.57)\end{array}$ & & \\
\hline
\end{tabular}

Note: ${ }^{* * *}, * *, *$ denote significance at the $1 \%, 5 \%, 10 \%$ levels, respectively. All models estimated using Poisson Pseudo Maximum Likelihood (PPML) methods. Robust standard errors (in parentheses) allow for clustering at the country-pair level. Pair as well as year specific importer and exporter fixed effects included but not reported. Number of observations: 27,200.

Figure 2 provides a quantitative interpretation based on the results on Table 1. The effect of a single Schengen border between a country pair leads, on average, to 
an increase in goods trade of about $2.6 \%$ and in services trade of $4.1 \%{ }^{13}$

The figure shows very clearly that other steps of EU integration have led to substantially more trade creation than Schengen. Mutual EU membership proves most important for trade integration. The cumulative effects of the customs union and the single market increased trade in services by $39.8 \%$ and goods trade by $122.6 \%$. The latter can be split up into a customs union effect of $53 \%$ and a single market effect of $69 \% .{ }^{14}$ Other RTAs boost trade in services by $20.2 \%$ and trade in goods by $35.3 \%$. The mutual adoption of the Euro in addition to EU membership is more important for goods trade $(15.3 \%)$ than for services trade (8.8\%).

\section{FiguRE 2}

Trade Creation Effects and Implied Ad Valorem Tariff Equivalents of Integration Policies

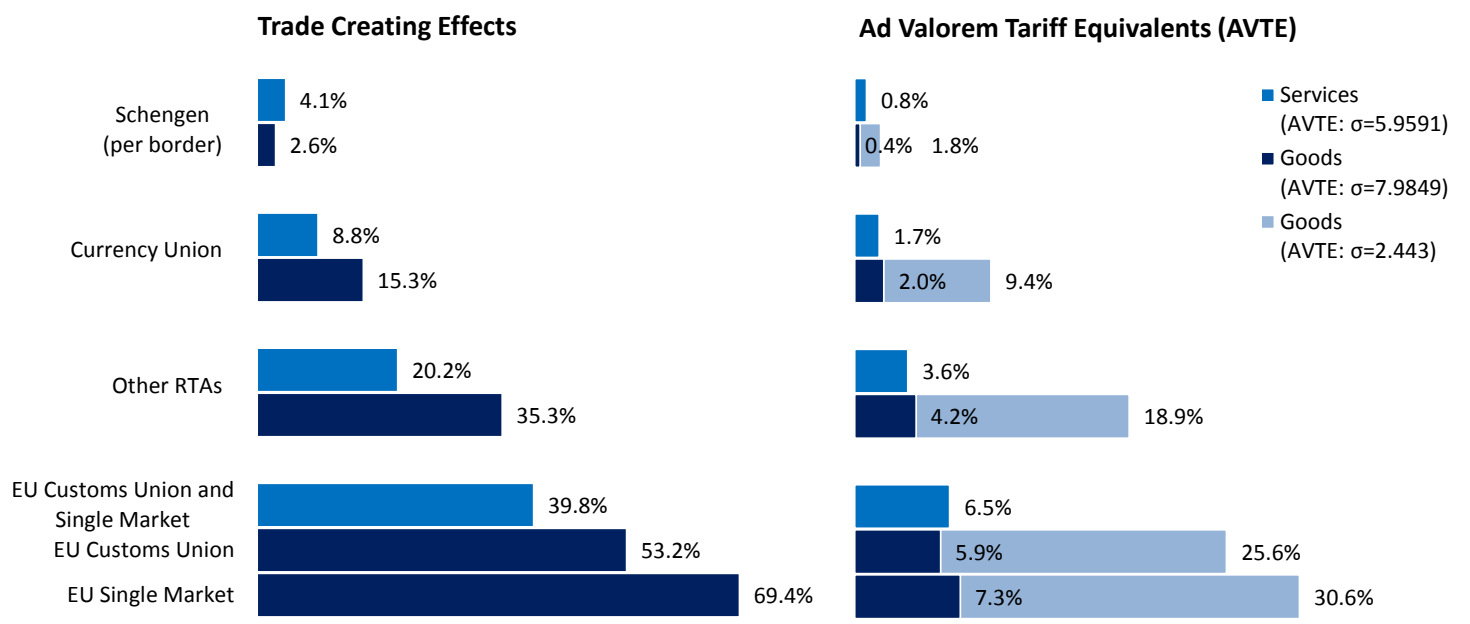

Note: Calculations based on Table 1.

\footnotetext{
${ }^{13}$ Estimated coefficients are translated by calculating $\% \Delta X^{s}=100 \times\left[e^{\beta^{s}}-1\right]$.

${ }^{14}$ Egan and Guimarães (2017) show that the Single Market still holds unrealized potential, as trade impediments continue to elicit business complaints and governments shield specific domestic industries from increased competition.
} 
To express these estimates as ad valorem tariff equivalents (AVTEs), we need the elasticity of substitution $\sigma^{s} .{ }^{15}$ We borrow two consistent external estimates from Egger et al. (2012), who report $\hat{\sigma}^{G}=7.9849$ and $\hat{\sigma}^{S}=5.9591$. For goods trade, our MFN result also suggests an internal elasticity of substitution estimate $\hat{\sigma}^{G}=2.443$; for services, however, we cannot estimate $\sigma^{S}$ due to the lack of tariffs. Note that our internal elasticity estimate is identified only via a relatively low number of observations. Its magnitude is thus substantially smaller compared to the literature and yields high AVTEs. Moreover, it cannot be compared consistently to the external services elasticity of substitution. We will therefore only use it for illustrative purposes, calculating intervals for ad valorem tariff equivalents for our baseline results, but resort to the consistent external estimates by Egger et al. (2012) for any further analyses.

The right hand side of Figure 2 depicts ad valorem tariff equivalents to the estimated trade effects. The combined EU effect equals a tariff reduction of 6.5 percentage points for services. The corresponding combined EU effect for goods trade (not depicted) ranges from 10.8 (using the elasticity of substitution by Egger et al., 2012) to 42.6 (using our own estimate) percentage points. The separated customs union effect on goods trade corresponds to an AVTE between 5.9\% and 25.6\%, and the single market implied AVTE lies between $7.3 \%$ and $30.6 \%$, depending on the chosen elasticity. The RTA effects are equivalent to a tariff reduction of 3.6 percentage points for services and between 4.2 and 18.9 percentage points for goods. Common membership in the Euro Area implies trade effects equivalent to a reduction in tariffs of 1.7 percentage points for trade in services and 2.0 to 9.4 percentage points for trade in goods. Finally, one additional Schengen border is

$$
15 \% \operatorname{AVTE}^{s}=100 \times\left[\left(e^{\beta^{s}}\right)^{\left(1 /\left(1-\sigma^{s}\right)\right)}-1\right]
$$


equivalent to a reduction in tariffs of 0.8 percentage points for trade in services and 0.37 to 1.8 percentage points for trade in goods.

Our findings add to the literature on the trade effects of European integration. However, this literature often does not control for the effects of the Schengen Agreement, which may bias the estimated effects of EU or Eurozone membership. To the largest extent, it also neither disaggregates between goods and services trade, nor does it incorporate domestic trade flows. The literature has produced very heterogeneous estimates of the trade effects of the Euro. ${ }^{16}$ As pointed out by Baldwin et al. (2008), earlier papers suffered from misspecified econometric models; avoiding these pitfalls and applying state-of-the-art modeling techniques, we generate very plausible estimates.

To compare the overall trade effect of the Schengen Agreement to those of the EU, the Eurozone, or other RTAs, we need to consider that the total pair-level effect of the Schengen Agreement increases with the number of borders crossed between trade partners. To evaluate this in more detail, we take into account that country pairs differ with respect to the number of Schengen borders crossed by bilateral landborne trade. When two internal borders are involved, the AVTE for goods amounts to $0.74 \%{ }^{17}$ with three border crossings, we get $1.11 \%$, and so forth; analogously for services trade. Accounting for the different trade structures of all EU-27 country pairs, the total average trade creating effect of Schengen is $2.81 \%$, corresponding to

\footnotetext{
${ }^{16}$ See the work of Micco et al. (2003), Flam and Nordström (2006) Baldwin and Taglioni (2007), Bun and Klaassen (2007). Berger and Nitsch (2008), Bergin and Lin (2012) and Camarero et al. (2014).

${ }^{17} 100 \times\left[\left(e^{2 \cdot \beta}\right)^{(1 /(1-\sigma))}-1\right]$, using the elasticity of substitution by Egger et al. (2012). Applying our own elasticity estimate for goods trade increases goods AVTEs about fivefold.
} 
an AVTE of between $0.46 \%$ and $1.02 \%$ (applying $\sigma_{1}^{T}=7.1948$ and $\sigma_{2}^{T}=3.8144$, an EU-27 sector-share weighted mean of $\sigma^{S}$ and $\sigma_{1}^{G}$ or $\sigma_{2}^{G}$ respectively.). ${ }^{18}$ Hence, the average trade creation induced by the Schengen Agreement alone is relatively low compared to the EU, the Euro, and other RTAs. ${ }^{19}$

Heterogeneity Across Member States. Clearly, diverse countries will be affected differently by Schengen, simply because geography, history, and specialization patterns imply that countries are heterogeneous with respect to the average number of Schengen borders that typical trade flows need to cross. To illustrate this, every country has its own break-down analogous to Figure 1. Calculating average AVTEs for available (geographically) European countries, ${ }^{20}$ we find that peripheral countries such as Estonia, Latvia, and Finland display the highest AVTEs $(0.83 \%$, 0.81\%, and 0.80\% respectively, see Appendix Table A5 for details). These countries typically trade across several internal Schengen borders. At the lower end, geographically central economies such as Germany or France display smaller AVTEs (0.34\% each). Ireland, whose main trade partners are the Schengen outsiders UK and US, features the lowest AVTE with $0.17 \%$. Interestingly, Figure 3 shows that

\footnotetext{
${ }^{18}$ In our data, $61 \%$ of EU-27 trade is in goods, $39 \%$ in services.

${ }^{19}$ We believe that a Schengen AVTE of below $1 \%$ is entirely plausible. Schengen does speed up the flow of traffic, but effects should not be overstated. Evidence from the US-Canadian border suggests that waiting times for trucks are about 20 minutes on average (see Appendix, Table A4). With an average transportation cost margin of about 10\% (Anderson and van Wincoop, 2004), such a tariff equivalent implies that identity checks increase transportation costs by at most $10 \%$. The 3\% tariff equivalent used in Aussilloux and Le Hir (2016) and Boehmer et al. (2016) would, in turn, imply an increase in transportation costs by an implausible $30 \%$.

${ }^{20}$ We average across sectors and trade partners.
} 
Schengen outsiders such as Russia or Turkey benefit from the removal of internal border controls, too. Their average trade costs savings from Schengen amount to $0.20 \%$ and $0.32 \%$ for goods and $0.57 \%$ and $1.08 \%$ for services trade, respectively.

\section{FigURE 3}

Average Share of Trade Affected by Schengen and Associated Tariff Equivalents

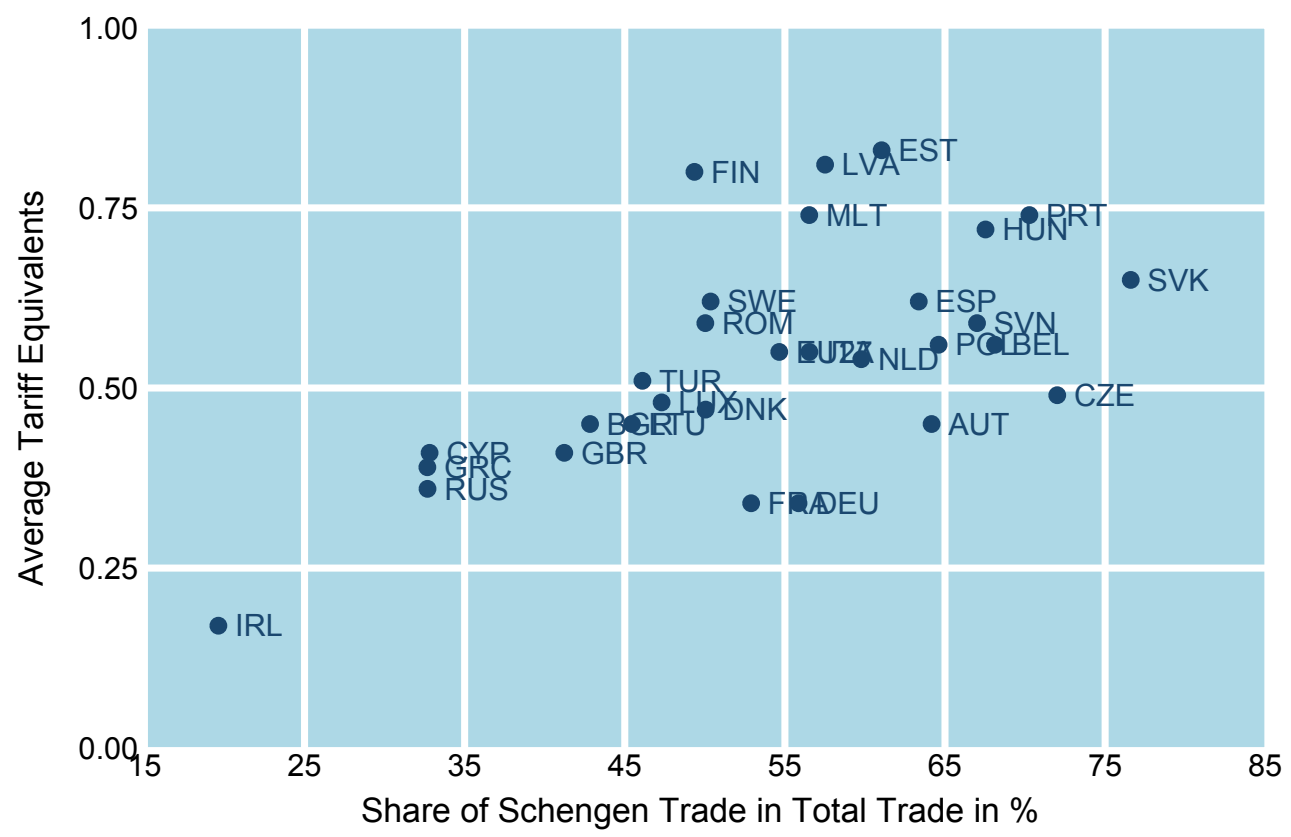

Note: Average tariff equivalents of membership to the Schengen Agreement, assuming sectoral trade elasticities provided by Egger et al. (2012).

Obviously, the overall magnitude of reported AVTEs depends on the assumed underlying trade elasticities, which we haven taken from Egger et al. (2012) to ensure comparability across sectors. As a sensitivity check, we instead assume a uniform elasticity of substitution of 6 and calculate AVTEs again. Clearly, assuming a higher (lower) elasticity of substitution for services (goods and total) trade, leads to lower (higher) AVTEs. Qualitatively, our key findings remain unchanged; see Table A6 in the Web Appendix for details.

Overall, our findings suggest an ad valorem tariff equivalent markedly below 
the 3\% assumed by Aussilloux and Le Hir (2016) or Boehmer et al. (2016), and Schengen effects for goods trade are clearly below the significantly larger long-run gravity estimates of previous studies such as Chen and Novy (2011), Davis and Gift (2014), or Aussilloux and Le Hir (2016). This implies that the spatial dimension and thus the number of Schengen borders to cross along the transit route matters for the identification of the Schengen effect and is preferable over using a simple indicator variable.

\section{ROBUSTNESS ANALYSIS}

Table 2 reports a number of robustness checks. Each row shows the estimated Schengen effects obtained by departing from some of the choices made in our baseline specification underlying the results reported in Table $1 .{ }^{21}$ For goods trade, column (2) does not control for MFN tariffs, while column (3) does.

First, Panel A of Table 2 varies the sample. In the benchmark model, we have excluded products which are most likely transported by pipeline, ship or train (gas, petrol, mining \& quarrying products). Including them, the effect of a Schengen border on bilateral goods exports increases from an AVTE of $0.37 \%$ to an AVTE of $0.50 \%(0.49 \%)$ in column (2) (column (3)); see row [1]. ${ }^{22}$ This can be taken as evidence that at least some of the sectoral trade is carried by trucks (e.g., coal, earths, metal). The AVTEs of the EU, the Eurozone, and other RTAs remain very similar to our previous findings.

In row [2], we address potential endogeneity concerns by excluding the three most

\footnotetext{
${ }^{21}$ Tables A7 - A16 in the Web Appendix provide full details.

${ }^{22}$ Assuming $\sigma^{G}=7.9849$.
} 
TABLE 2

Robustness: Schengen Effects in Alternative Models

Dep. var.: Bilateral Exports

\begin{tabular}{|c|c|c|c|c|}
\hline & Total Trade & Goods (S1) & Goods (S2) & Services \\
\hline & $(1)$ & $(2)$ & $(3)$ & $(4)$ \\
\hline \multicolumn{5}{|l|}{ PANEL A: Alternative Sample Composition } \\
\hline [1] Including mining, gas, petrol & $\begin{array}{l}0.007 \\
(0.01)\end{array}$ & $\begin{array}{c}0.035^{* * *} \\
(0.01)\end{array}$ & $\begin{array}{c}0.034^{* * *} \\
(0.01)\end{array}$ & $\begin{array}{c}0.040^{*} \\
(0.02)\end{array}$ \\
\hline \multirow[t]{2}{*}{ [2] Excluding main bilateral trade partners } & -0.003 & $0.017^{* * *}$ & $0.017^{* * *}$ & $0.043^{* *}$ \\
\hline & $(0.01)$ & $(0.01)$ & $(0.01)$ & $(0.02)$ \\
\hline \multirow[t]{2}{*}{ [3] Intracontinental trade only (European Sample) } & 0.005 & $0.034^{* * *}$ & $0.034^{* * *}$ & $0.057 * * *$ \\
\hline & $(0.01)$ & $(0.01)$ & $(0.01)$ & $(0.02)$ \\
\hline \multicolumn{5}{|c|}{ PANEL B: Alternative Measurement of Treatment } \\
\hline \multirow[t]{2}{*}{ [4] Treating intercontinental trade flows } & $0.024^{* *}$ & $0.050^{* * *}$ & $0.048^{* * *}$ & $0.073^{* * *}$ \\
\hline & $(0.01)$ & $(0.01)$ & $(0.01)$ & $(0.03)$ \\
\hline \multirow[t]{2}{*}{ [5] Schengen as binary variable $[0 ; 1]$} & $0.030 * *$ & $0.070 * * *$ & $0.072^{* * *}$ & 0.065 \\
\hline & $(0.01)$ & $(0.02)$ & $(0.02)$ & $(0.04)$ \\
\hline \multirow[t]{2}{*}{ [6] Chen and Novy (2011) indicator $[0 ; 0.5 ; 1]$} & $0.161^{* * *}$ & $0.254^{* * *}$ & $0.247^{* * *}$ & $0.300^{* * *}$ \\
\hline & $(0.03)$ & $(0.03)$ & $(0.03)$ & $(0.06)$ \\
\hline \multicolumn{5}{|l|}{ PANEL C: Alternative Econometric Choices } \\
\hline \multirow{2}{*}{ [7] Pooled over sectors } & 0.0003 & $0.026^{* * *}$ & $0.026^{* * *}$ & $0.040^{* *}$ \\
\hline & $(0.01)$ & $(0.01)$ & $(0.01)$ & $(0.02)$ \\
\hline \multirow[t]{2}{*}{ [8] Baier and Bergstrand (2009) MR-Terms } & 0.005 & $0.037^{* * *}$ & $0.038^{* * *}$ & 0.034 \\
\hline & $(0.01)$ & $(0.01)$ & $(0.01)$ & $(0.02)$ \\
\hline \multirow[t]{2}{*}{ [9] No bilateral fixed effects } & -0.130 & -0.084 & $-0.128^{* * *}$ & -0.148 \\
\hline & $(0.08)$ & $(0.07)$ & $(0.06)$ & $(0.09)$ \\
\hline \multicolumn{5}{|l|}{ PANEL D: Heterogeneity } \\
\hline \multirow[t]{2}{*}{ [10] Schengen Bin [1] } & 0.026 & $0.084^{* * *}$ & $0.089^{* * *}$ & -0.048 \\
\hline & $(0.02)$ & $(0.02)$ & $(0.02)$ & $(0.06)$ \\
\hline \multirow[t]{2}{*}{ Schengen Bin [2] } & 0.036 & $0.113^{* * *}$ & $0.117^{* * *}$ & -0.012 \\
\hline & $(0.02)$ & $(0.03)$ & $(0.03)$ & $(0.07)$ \\
\hline \multirow[t]{2}{*}{ Schengen Bin $[3 ; 8]$} & $0.054^{*}$ & $0.140^{* * *}$ & $0.138^{* * *}$ & $0.169^{*}$ \\
\hline & $(0.03)$ & $(0.03)$ & $(0.03)$ & $(0.09)$ \\
\hline
\end{tabular}

Note: Specification 1 (S1) does not explicitly control for tariffs, while specification 2 (S2) does. ${ }^{* * *},{ }^{* *},{ }^{*}$, denote significance at the $1 \%, 5 \%$, and $10 \%$ level, respectively. Robust clustered standard errors reported in parentheses. For details see Tables A7 - A16 in the Appendix. Default estimation technique is PPML (unless stated otherwise).

important trade partners of each country from the sample, as trade shocks pertaining to them could have driven the decision to join the Schengen area. The results support our previous findings. The exclusion of important trade partners reduces the magnitude of a Schengen border on goods trade to an AVTE of 0.24\%, while it 
slightly increases the magnitude on services trade to $0.87 \% .^{23}$ The magnitudes of the EU, the Eurozone, or other RTA effects are reduced. ${ }^{24}$

Row [3] focuses on intracontinental European trade only (treating Turkey and Russia as geographical Europe). Results remain very similar to our benchmark results. As expected, coefficients increase slightly in magnitude, as all extracontinental trade flows are excluded from the sample. Focusing on intracontinental European trade only leads to an AVTE on goods trade of $0.49 \%$ and $1.14 \%$ on services trade. Similarly, the EU, the Euro area, and further RTA effects increase in magnitude.

Second, Panel B looks at alternative measurements of treatment. In row [4], we assume that intercontinental trade of third countries with Schengen members crosses, on average, one internal Schengen border. While extra-Schengen air-borne trade is unlikely to benefit from Schengen, sea-borne trade may well benefit, as goods are transported from major seaports to the interior of the continent. ${ }^{25}$ As expected, treating intercontinental trade by one Schengen border on average slightly inflates estimates and leads to statistically significant estimates for total trade. We find AVTEs of $0.39 \%$ for total trade, ${ }^{26} 0.71 \%$ (0.68\%) for goods in column (2) (column (3)), and $1.46 \%$ for services. All other controls remain similar in magnitude relative to our benchmark results.

\footnotetext{
${ }^{23}$ Assuming $\sigma^{S}=5.9591$.

${ }^{24}$ Note that these estimates are subject to sample selection bias. The direction of the bias depends on the systematic characteristics of the trade partners dropped.

${ }^{25}$ Note that no information on transport modes for global trade, or even trade within Europe, is available. Hence, assuming an average of one border crossing for trade that does not originate in geographical Europe only provides an approximation of treated intercontinental trade values.
}

${ }^{26}$ Assuming $\sigma^{T}=7.1948$. 
Row [5] employs a binary Schengen indicator as in Davis and Gift (2014) or Aussilloux and Le Hir (2016). This more than doubles the estimated Schengen effect. In addition, the trade effect on services trade is now less accurately measured. ${ }^{27}$ The trade effects of the EU, the Euro, and other RTAs remain close to our benchmark findings.

Similarly, coding whether both, one or none of the trade partners are Schengen members $($ Schengen $=0,0.5,1)$, as in Chen and Novy (2011), strongly inflates the Schengen estimates (row [6]), suggesting an AVTE of 3.6\% (3.5\%) for goods in column (2) (column (3)) and of $5.9 \%$ for services trade. Comparing these estimates to the ones obtained using our own measure of treatment suggests that ignoring the geographic features of the Schengen area leads to an overestimation of the Schengen Agreement's trade effects. Recall that, accounting for the different trade structures of all EU-27 country pairs, the total average trade creating effect of Schengen obtained using our more exact measure of treatment is $2.81 \%$, i.e., an AVTE of only $0.46 \%$.

Panel C varies econometric choices. Row [7] pools over all 35 sub-sectors (see Table A3 in the Appendix) instead of aggregating trade, with standard errors allowing for clustering at the country-pair-subsector level. ${ }^{28}$ This increases the number

\footnotetext{
${ }^{27}$ Note that this binary Schengen indicator disregards the geographical component of Schengen but simply measures the average trade effect of both trade partners being Schengen members, whereas we measure the average trade effect of one Schengen border en route between two countries. By accounting for the spatial distribution of Schengen borders, our treatment measure allows a more sophisticated disentanglement of the actual border effects at work.

${ }^{28}$ Multiway clustering addresses intraclass correlation at the subsectoral and at the country pair level, hedging against the risk of inflating Type I error rates.
} 
of observations from 27,200 to 380,800 for goods and to 514,539 for services trade. Next to country pair fixed effects, we apply year specific importer, exporter, and sector fixed effects. ${ }^{29}$ This choice leaves our baseline results given in Table 1 virtually unchanged in terms of sign, magnitude, and level of significance.

In the following we deviate from our preferred and state-of-the-art methodology. We find that these choices make it harder to disentangle the trade effects of integration, not only for Schengen but also for other measures such as the EU or RTAs. In row [8], we follow a different approach in controlling for multilateral resistance. Instead of using year specific importer and exporter fixed effects, we follow Baier and Bergstrand (2009) by using a Taylor Series expansion to explicitly control for unobserved multilateral resistances. This strategy requires us to additionally control for exporter supply and importer demand, which we extract from WIOD. We construct a vector $\mathbf{M R}_{i j, t}^{s}$ that contains first-order approximations of the terms $\Omega_{i, t}^{s}$ and $\Omega_{j, t}^{s}$ for all types of trade costs. ${ }^{30}$ This change in methodology only marginally increases the estimated Schengen effect for goods trade and slightly decreases that for services trade, leading to a lower level of significance on the latter. This is also true for the EU, the Euro, and the RTA trade effects. Nevertheless, the overall order

\footnotetext{
${ }^{29}$ Choosing country pair-sector fixed effects and year specific importer and exporter fixed effects instead does not change our results.

${ }^{30}$ More precisely, multilateral resistance terms are calculated based on a linearized version of the canonical trade model that underlies equation (1). They are calculated for any trade cost $\operatorname{proxy} \phi_{i j}$ as $M R_{-} \phi_{i j, t}^{s}=\left[\left(\sum_{k=1} \lambda_{k, t}^{s} \phi_{i k}\right)+\left(\sum_{m=1} \delta_{m, t}^{s} \phi_{m j}\right)-\left(\sum_{k=1} \sum_{m=1} \lambda_{k, t}^{s} \delta_{m, t}^{s} \phi_{k m}\right)\right]$, where $\delta_{m, t}^{s}$ denotes country $m$ 's share in total world supply, $S_{m, t}^{s} / S_{t}^{s}$ in sector $s$, and $\lambda_{k, t}^{s}$ is an analogously defined sectoral demand share. $\phi_{i j}$ can be the log of distance, an adjacency dummy, a dummy for intranational trade, or various trade policy dummies governing the membership of a pair in Schengen, the EU, the Eurozone, or other RTAs.
} 
of magnitude of the estimated coefficients remains very similar and thus leaves our key findings unchanged.

If we do not control for time-invariant determinants that might jointly affect trade integration (i.e., Schengen, EU, Euro, RTAs) and export volumes, we face omitted variable bias and potential endogeneity of policy variables. In row [9], we replace bilateral fixed effects by explicit trade cost proxies, such as bilateral distance, dummies for adjacency, intrantional trade, and common language. As expected, this leads to implausible effects not only on Schengen membership, but also on all other trade policy variables - except for the Eurozone. This result is reminiscent of Baier and Bergstrand (2007), who show that bilateral fixed effects are a crucial ingredient in the identification of causal effects of trade agreements because common but unobserved time-invariant determinants of both trade and the conclusion of agreements lead to biased estimates if they are not accounted for.

Finally, Panel D actually tests the heterogeneous effects of the Schengen Agreement, additionally to calculating them for all countries in our sample in the previous section. To approach this, we break the Schengen variable into subsets based on the number of borders crossed. We take bins which contain observations with one Schengen border, observations with two Schengen borders, and those with three or more (up to eight) Schengen borders. ${ }^{31}$ Zero Schengen borders are our reference category. Similar to the baseline specification, the heterogeneity across the number of Schengen borders to be crossed is best identified for goods trade, as these are generally the most stable results - total trade faces an aggregation bias and services

\footnotetext{
${ }^{31}$ We have very little observations with more than 3 Schengen borders. This leads to issues when trying to identify effects empirically for these observations. We thus take them together in one bin and see this as an additional exercise to calculating the heterogeneous effects separately.
} 
trade results are only marginally statistically significant. We find positive effects for total trade, but only the effect on three or more Schengen borders is statistically significant on the $10 \%$ level. Similarly, we find positive and statistically significant effects on goods trade, the size of them monotonically depending on the number of borders crossed. While Schengen increased trade for pairs with one border by $9.2 \%$, those with two borders already experience a trade increase by $12.3 \%$ and the trade of country pairs with three or more borders increased on average by $15 \%$. For services this again looks different. While we cannot identify a statistically significant effect for one or two borders relative to zero borders, three or more borders exert a statistically significant effect and increase services trade for these pairs by $18.4 \%$. The stronger effect on services than on goods for many Schengen borders is again not surprising, as Schengen also promotes the mobility of individuals, which is more important for the cross-border provision of services than of goods and might be even more relevant for pairs with many Schengen borders. Overall, this shows that - due to the skewed distribution of the number of Schengen borders - it is not easy to empirically identify the heterogeneity across countries, particularly for services trade.

\section{CONCLUSION}

In the present paper, we analyze the impact of the Schengen Agreement on trade in goods and services. We contribute to the literature by recognizing the spatial structure of the Schengen treatment, fully accounting for other European integration steps, and taking transit routes and the number of Schengen borders to be crossed en route into account.

Using a more accurate definition of the Schengen treatment and making full use 
of the newest methodological advances, our PPML results imply a ranking of trade policy effects. Schengen significantly helps fostering trade integration in goods and services trade, namely by $2.6 \%$ and $4.1 \%$ per Schengen border, respectively, in our preferred specification. Drawing on structural estimates of the sectoral elasticity of substitution by Egger et al. (2012), this equals an ad valorem tariff equivalent of $0.37 \%$ in goods trade and $0.80 \%$ in services trade. The total average trade creation effect of Schengen is about $2.81 \%$, corresponding to a drop in tariffs of about 0.46 percentage points.

Quite plausibly, in comparison with EU and Eurozone membership, and with other RTAs, the average trade creation induced by the Schengen Agreement alone is relatively low. EU membership boosts trade in goods by $122.6 \%$ (53.2\% due to the customs union and $69.4 \%$ due to the single market) and in services by $39.8 \%$, respectively. Other RTAs increase trade in goods by an additional $35.3 \%$ and in services by $20.2 \%$. Common membership in the Eurozone is again more important for goods trade than for services trade, $15.3 \%$ and $8.8 \%$, respectively.

We find substantial heterogeneity across countries, because geography, history, and specialization patterns imply that countries are heterogeneous with respect to the average number of Schengen borders that their trade flows need to cross. Peripheral countries benefit most from Schengen. Interestingly, through transit effects, Schengen outsiders also benefit from the removal of border controls within the Schengen area.

Finally, although the trade promoting effects of Schengen seem relatively small compared to other integration measures, abolishing the Schengen area implies bearing further cost which are not as easily quantifiable. The free movement of people can be considered a climax in the ongoing process of European integration which, if 
forfeited, might jeopardize the European idea and many of its political achievements. In this context, a question to be addressed in future research should be whether an ongoing European integration process could be ensured in spite of (rather than because of) ending the Schengen Agreement. 


\section{References}

Ademmer, E., Barsbai, T., Lücke, M., Stöhr, T., 2015. 30 Years of Schengen: Internal Blessing, External Curse? Tech. rep., Kiel Policy Brief 88.

Anderson, J., van Wincoop, E., 2004. Trade Costs. Journal of Economic Literature $42,691-751$.

Anderson, J., Yotov, Y., 2015. Terms of Trade and Global Efficiency Effects of Free Trade Agreements, 1990-2002. Journal of International Economics 99, 279-298.

Aussilloux, V., Le Hir, B., 2016. The Economic Consequences of Rolling back Schengen. Tech. rep., France Strategie Policy Brief.

Baier, S., Bergstrand, J., 2007. Do Free Trade Agreements Actually Increase Members' International Trade? Journal of International Economics 71 (1), 72-95.

Baier, S., Bergstrand, J., 2009. Bonus vetus OLS: A Simple Method for Approximating International Trade-Cost Effects Using the Gravity Equation. Journal of International Economics 77 (1), 77-85.

Baldwin, R., DiNino, V., Fontagné, L., De Santis, R., Taglioni, D., 2008. Study on the Impact of the Euro on Trade and Foreign Direct Investment. Tech. rep., Directorate General Economic and Financial Affairs (DG ECFIN), European Commission.

Baldwin, R., Taglioni, D., 2007. Trade Effects of the Euro: A Comparison of Estimators. Journal of Economic Integration 22 (4), 780-818.

Berger, H., Nitsch, V., 2008. Zooming Out: The Trade Effect of the Euro in Historical Perspective. Journal of International Money and Finance 27 (8), 1244-1260.

Bergin, P., Lin, C., 2012. The Dynamic Effects of a Currency Union on Trade. Journal of International Economics 87 (2), 191-204.

Bergstrand, J., Larch, M., Yotov, Y., 2015. Economic Integration Agreements, Border Effects, and Distance Elasticities in the Gravity Equation. European Economic Review 78, 307-327.

Boehmer, M., Limbers, J., Pivac, A., Weinelt, H., 2016. Departure from the Schengen Agreement - Macroeconomic Impacts of Germany and the Countries of the European Union. GED Study on behalf of Bertelsmann Foundation, Prognos AG.

Bun, M., Klaassen, F., 2007. The Euro Effect on Trade is Not as Large as Commonly Thought. Oxford Bulletin of Economics and Statistics 69 (4), 473-496. 
Camarero, M., Gómez, E., Tamarit, C., 2014. Is the Euro Effect on Trade So Small After All? New Evidence Using Gravity Equations with Panel Cointegration Techniques. Economics Letters 124 (1), 140-142.

Chen, N., Novy, D., 2011. Gravity, Trade Integration, and Heterogeneity across Industries. Journal of International Economics 85 (2), 206-221.

Dai, M., Yotov, Y., Zylkin, T., 2014. On the Trade-Diversion Effects of Free Trade Agreements. Economics Letters 122 (2), 321-325.

Davis, D., Gift, T., 2014. The Positive Effects of the Schengen Agreement on European Trade. World Economy 37 (11), 1541-1557.

Egan, M., Guimarães, M. H., 2017. The Single Market: Trade Barriers and Trade Remedies. Journal of Common Market Studies 55 (2), 294-311.

Egger, P. H., Larch, M., Staub, K. E., 2012. Trade preferences and bilateral trade in goods and services: A structural approach. CEPR Discussion Paper No. DP9051.

Flam, H., Nordström, H., 2006. Trade Volume Effects of the Euro: Aggregate and Sector Estimates. Seminar Paper No. 746, Institute for International Economic Studies.

Head, K., Mayer, T., 2014. Gravity Equations: Workhorse, Toolkit, and Cookbook. in G. Gopinath, E. Helpman and K. Rogoff (eds.), Handbook of International Economics Vol. 4, 131-195.

Micco, A., Stein, E., Ordoñez, G., 2003. The Currency Union Effect on Trade: Early Evidence from EMU. Economic Policy 18 (37), 315-356.

Monar, J., 2014. Justice and Home Affairs. Journal of Common Market Studies 52 (S1), 141-156.

Piermartini, R., Yotov, Y., 2016. Estimating trade policy effects with structural gravity. WTO Staff Working Paper, No. ERSD-2016-10.

Samuelson, P. A., 1954. The transfer problem and transport costs, ii: Analysis of effects of trade impediments. The Economic Journal 64 (254), 264-289.

Santos Silva, J., Tenreyro, S., 2006. The Log of Gravity. Review of Economics and Statistics 88 (4), 641-658.

Santos Silva, J., Tenreyro, S., 2011. Further Simulation Evidence on the Performance of the Poisson Pseudo-Maximum Likelihood Estimator. Economics Letters 112 (2), 220-222. 
Timmer, M., Dietzenbacher, E., Los, B., Stehrer, R., Vries, G., 2015. An Illustrated User Guide to the World Input-Output Database: the Case of Global Automotive Production. Review of International Economics 23 (3), 575-605.

Trauner, F., Ripoll Servent, A., 2016. The Communitarization of the Area of Freedom, Security and Justice: Why Institutional Change does not Translate into Policy Change. Journal of Common Market Studies 54 (6), 1417-1432.

Yotov, Y., 2012. A Simple Solution to the Distance Puzzle in International Trade. Economics Letters 117 (3), 794-798. 


\title{
WEB APPENDIX to The Trade Effects of Border Controls: \\ Evidence from the European Schengen Agreement
}

\author{
Gabriel Felbermayr*, Jasmin Gröschl’, and Thomas Steinwachs ${ }^{\ddagger}$
}

March 17, 2017

*Ifo Institute - Leibniz Institute for Economic Research at the University of Munich, Poschingerstr. 5, 81679 Munich, Germany; LMU, CESifo \& GEP; felbermayr@ifo.de

†Ifo Institute, Poschingerstr. 5, 81679 Munich, Germany; CESifo; groeschl@ifo.de

†Ifo Institute, Poschingerstr. 5, 81679 Munich, Germany; steinwachs@ifo.de 


\section{A Web Appendix}

TABle A1

Summary Statistics

\begin{tabular}{lrrrrr}
\hline variable & $\mathbf{N}$ & mean & sd & max & min \\
\hline Exports $_{i j, t}$ & 27,200 & 20.39 & 272.13 & 12385.98 & 0.00 \\
Schengen $_{i j, t}(\mathrm{~S}=1)$ & 27,200 & 0.79 & 1.31 & 8.00 & 0.00 \\
Schengen $_{i j, t}[0 ; 1]$ & 27,200 & 0.99 & 1.25 & 8.00 & 0.00 \\
Schengen $_{i j, t}[0 ; 0.5 ; 1]$ & 27,200 & 0.13 & 0.34 & 1.00 & 0.00 \\
Schengen $_{i j, t}$ & 0.34 & 0.35 & 1.00 & 0.00 \\
Both EU $_{i j, t}$ & 27,200 & 0.26 & 0.44 & 1.00 & 0.00 \\
Both Euro $_{i j, t}$ & 27,200 & 0.08 & 0.27 & 1.00 & 0.00 \\
Other RTA $_{i j, t}$ & 27,200 & 0.23 & 0.42 & 1.00 & 0.00 \\
ln Supply $_{i, t}$ & 27,200 & 13.03 & 1.82 & 17.06 & 8.78 \\
ln Demand $_{j, t}$ & 27,200 & 12.33 & 1.82 & 16.54 & 8.26 \\
ln Distance $_{i j}$ & 27,200 & 8.03 & 1.14 & 9.81 & 2.13 \\
Adjacency $_{i j}$ & 27,200 & 0.06 & 0.23 & 1.00 & 0.00 \\
Common Language $_{i j}$ & 27,200 & 0.05 & 0.22 & 1.00 & 0.00 \\
Colony $_{i j}$ & 27,200 & 0.04 & 0.19 & 1.00 & 0.00 \\
${\text { Colony post } 1945_{i j}}_{\text {Same Country }_{i j}}$ & 27,200 & 0.01 & 0.12 & 1.00 & 0.00 \\
lnMFN $_{i j, t}$ & 27,200 & 0.02 & 0.14 & 1.00 & 0.00 \\
N $_{\text {Note Sum }}$ & 27,200 & 0.08 & 0.09 & 0.50 & 0.00 \\
\hline
\end{tabular}

Note: Summary statistics for the complete sample and total trade. 
TABle A2

WIOD Country List

\begin{tabular}{ll}
\hline ISO Code & Country \\
\hline AUS & Australia \\
AUT & Austria \\
BEL & Belgium \\
BGR & Bulgaria \\
BRA & Brazil \\
CAN & Canada \\
CHN & China, People's Rep. of \\
CYP & Cyprus \\
CZE & Czech Republic \\
DEU & Germany \\
DNK & Denmark \\
ESP & Spain \\
EST & Estonia \\
FIN & Finland \\
FRA & France \\
GBR & United Kingdom \\
GRC & Greece \\
HUN & Hungary \\
IDN & Indonesia \\
IND & India \\
IRL & Ireland \\
ITA & Italy \\
JPN & Japan \\
KOR & Korea \\
LTU & Lithuania \\
LUX & Luxembourg \\
LVA & Latvia \\
MEX & Mexico \\
MLT & Malta \\
NLD & Netherlands \\
POL & Poland \\
PRT & Portugal \\
ROM & Romania \\
RUS & Russia \\
SVK & Slovak Republic \\
SVN & Slovenia \\
SWE & Sweden \\
TUR & Turkey \\
TWN & Taiwan \\
USA & United States \\
\hline &
\end{tabular}




\section{TABLE A3 WIOD Sector List}

\begin{tabular}{|c|c|c|}
\hline Sector & ISIC rev.3 & Description \\
\hline $\mathrm{C} 01$ & AtB & Agriculture, Hunting, Forestry and Fishing \\
\hline $\mathrm{C} 02$ & $\mathrm{C}$ & Mining and Quarrying \\
\hline $\mathrm{C} 03$ & $15 \mathrm{t} 16$ & Food, Beverages and Tobacco \\
\hline $\mathrm{C} 04$ & $17 \mathrm{t} 18$ & Textiles and Textile Products \\
\hline $\mathrm{C} 05$ & 19 & Leather, Leather and Footwear \\
\hline $\mathrm{C} 06$ & 20 & Wood and Products of Wood and Cork \\
\hline $\mathrm{C} 07$ & $21 \mathrm{t} 22$ & Pulp, Paper, Paper, Printing and Publishing \\
\hline $\mathrm{C} 08$ & 23 & Coke, Refined Petroleum and Nuclear Fuel \\
\hline $\mathrm{C} 09$ & 24 & Chemicals and Chemical Products \\
\hline $\mathrm{C} 10$ & 25 & Rubber and Plastics \\
\hline $\mathrm{C} 11$ & 26 & Other Non-Metallic Mineral \\
\hline $\mathrm{C} 12$ & $27 \mathrm{t} 28$ & Basic Metals and Fabricated Metal \\
\hline $\mathrm{C} 13$ & 29 & Machinery, Nec \\
\hline $\mathrm{C} 14$ & $30 \mathrm{t} 33$ & Electrical and Optical Equipment \\
\hline $\mathrm{C} 15$ & $34 \mathrm{t} 35$ & Transport Equipment \\
\hline $\mathrm{C} 16$ & $36 \mathrm{t} 37$ & Manufacturing, Nec; Recycling \\
\hline $\mathrm{C} 17$ & $\mathrm{E}$ & Electricity, Gas and Water Supply \\
\hline $\mathrm{C} 18$ & $\mathrm{~F}$ & Construction \\
\hline $\mathrm{C} 19$ & 50 & Sale, Maintenance and Repair of Motor Vehicles and Motorcycles; Retail Sale of Fuel \\
\hline $\mathrm{C} 20$ & 51 & Wholesale Trade and Commission Trade, Except of Motor Vehicles and Motorcycles \\
\hline $\mathrm{C} 21$ & 52 & Retail Trade, Except of Motor Vehicles and Motorcycles; Repair of Household Goods \\
\hline $\mathrm{C} 22$ & $\mathrm{H}$ & Hotels and Restaurants \\
\hline $\mathrm{C} 23$ & 60 & Inland Transport \\
\hline $\mathrm{C} 24$ & 61 & Water Transport \\
\hline $\mathrm{C} 25$ & 62 & Air Transport \\
\hline $\mathrm{C} 26$ & 63 & Other Supporting and Auxiliary Transport Activities; Activities of Travel Agencies \\
\hline $\mathrm{C} 27$ & 64 & Post and Telecommunications \\
\hline $\mathrm{C} 28$ & $\mathrm{~J}$ & Financial Intermediation \\
\hline $\mathrm{C} 29$ & 70 & Real Estate Activities \\
\hline C30 & $71 \mathrm{t} 74$ & Renting of M\&Eq and Other Business Activities \\
\hline C31 & $\mathrm{L}$ & Public Admin and Defense; Compulsory Social Security \\
\hline C32 & M & Education \\
\hline C33 & $\mathrm{N}$ & Health and Social Work \\
\hline C34 & $\mathrm{O}$ & Other Community, Social and Personal Services \\
\hline C35 & $\mathrm{P}$ & Private Households with Employed Persons \\
\hline
\end{tabular}


TABle A4

Waiting time for commercial vehicles and traffic volume at US-Canadian border checkpoints, 2014

\begin{tabular}{|c|c|c|c|c|c|}
\hline \multirow[b]{2}{*}{ Border Station } & \multicolumn{3}{|c|}{ Waiting time (minutes) } & \multirow[b]{2}{*}{ \# vehicles } & \multirow[b]{2}{*}{ Station share } \\
\hline & mean & $\min$ & $\max$ & & \\
\hline ME: Calais & 0 & 0 & 0 & 62,352 & $1.1 \%$ \\
\hline ME: Houlton & 1 & 0 & 6 & 84,043 & $1.4 \%$ \\
\hline ME: Jackman & 0 & 0 & 0 & 84,755 & $1.5 \%$ \\
\hline ME: Madawaska & 3 & 0 & 15 & 19,238 & $0.3 \%$ \\
\hline MI: Detroit & 20 & 10 & 30 & $1,600,000$ & $27.6 \%$ \\
\hline MI: Port Huron & 7 & 0 & 37 & 778,268 & $13.4 \%$ \\
\hline MI: Sault Ste. Marie & 5 & 0 & 15 & 38,932 & $0.7 \%$ \\
\hline MN: Intertiol Falls & 0 & 0 & 0 & 16,528 & $0.3 \%$ \\
\hline MT: Sweetgrass & 20 & 10 & 45 & 145,803 & $2.5 \%$ \\
\hline ND: Pembi & 18 & 12 & 36 & 229,079 & $3.9 \%$ \\
\hline NY: Alexandria Bay & 15 & NA & NA & 192,551 & $3.3 \%$ \\
\hline NY: Buff.-Niagara Falls & 24 & 11 & 36 & 962,076 & $16.6 \%$ \\
\hline NY: Champ.-Rouses Pt. & 45 & NA & NA & 285,195 & $4.9 \%$ \\
\hline NY: Massena & 0 & 0 & 0 & 23,188 & $0.4 \%$ \\
\hline NY: Ogdensburg & 10 & NA & NA & 37,726 & $0.7 \%$ \\
\hline VT: Derby Line & 20 & NA & NA & 97,836 & $1.7 \%$ \\
\hline VT: Highgate Springs & 15 & NA & NA & 93,914 & $1.6 \%$ \\
\hline VT: Norton & 0 & 0 & 0 & 11,161 & $0.2 \%$ \\
\hline WA: Blaine & 8 & 0 & 0 & 367,994 & $6.3 \%$ \\
\hline WA: Lynden & 10 & NA & NA & 41,580 & $0.7 \%$ \\
\hline WA: Point Roberts & 10 & NA & NA & 18,121 & $0.3 \%$ \\
\hline WA: Sumas & 25 & 10 & 100 & 149,361 & $2.6 \%$ \\
\hline Other & NA & NA & NA & 462,508 & $8.0 \%$ \\
\hline Weighted Mean / Sum & 18 & & & $5,802,209$ & $100 \%$ \\
\hline
\end{tabular}


TABLE A5

Ad Valorem Tariff Equivalents due to Schengen, by Country

\begin{tabular}{|c|c|c|c|c|c|c|c|c|}
\hline \multirow[t]{3}{*}{ Country } & \multicolumn{5}{|c|}{ Ad Valorem Tariff Equivalents } & \multicolumn{3}{|c|}{ Share of Schengen Trade } \\
\hline & \multicolumn{2}{|c|}{ Goods } & \multirow{2}{*}{$\begin{array}{c}\text { Services } \\
\sigma^{S}=5.9591\end{array}$} & \multicolumn{2}{|c|}{ Total Trade } & \multirow{2}{*}{ Goods } & \multirow[t]{2}{*}{ Services } & \multirow[t]{2}{*}{ Total Trade } \\
\hline & $\sigma_{1}^{G}=7.9849$ & $\sigma_{2}^{G}=2.443$ & & $\sigma_{1}^{T}=7.1948$ & $\sigma_{2}^{T}=3.8144$ & & & \\
\hline EST & $0.63 \%$ & $3.08 \%$ & $1.20 \%$ & $0.83 \%$ & $1.83 \%$ & $68.87 \%$ & $52.50 \%$ & $61.04 \%$ \\
\hline LVA & $0.64 \%$ & $3.15 \%$ & $1.09 \%$ & $0.81 \%$ & $1.80 \%$ & $67.76 \%$ & $50.20 \%$ & $57.51 \%$ \\
\hline FIN & $0.67 \%$ & $3.26 \%$ & $1.12 \%$ & $0.80 \%$ & $1.76 \%$ & $52.29 \%$ & $43.26 \%$ & $49.35 \%$ \\
\hline MLT & $0.42 \%$ & $2.05 \%$ & $1.15 \%$ & $0.74 \%$ & $1.65 \%$ & $51.16 \%$ & $59.95 \%$ & $56.52 \%$ \\
\hline PRT & $0.64 \%$ & $3.14 \%$ & $0.97 \%$ & $0.74 \%$ & $1.64 \%$ & $79.40 \%$ & $58.41 \%$ & $70.27 \%$ \\
\hline HUN & $0.60 \%$ & $2.94 \%$ & $1.03 \%$ & $0.72 \%$ & $1.60 \%$ & $73.13 \%$ & $55.39 \%$ & $67.53 \%$ \\
\hline SVK & $0.53 \%$ & $2.60 \%$ & $0.96 \%$ & $0.65 \%$ & $1.43 \%$ & $79.37 \%$ & $69.53 \%$ & $76.60 \%$ \\
\hline SWE & $0.58 \%$ & $2.84 \%$ & $0.73 \%$ & $0.62 \%$ & $1.38 \%$ & $60.83 \%$ & $36.08 \%$ & $50.36 \%$ \\
\hline ESP & $0.47 \%$ & $2.29 \%$ & $0.94 \%$ & $0.62 \%$ & $1.37 \%$ & $67.12 \%$ & $58.03 \%$ & $63.36 \%$ \\
\hline ROM & $0.48 \%$ & $2.36 \%$ & $0.80 \%$ & $0.59 \%$ & $1.30 \%$ & $57.13 \%$ & $42.77 \%$ & $50.03 \%$ \\
\hline SVN & $0.51 \%$ & $2.47 \%$ & $0.78 \%$ & $0.59 \%$ & $1.30 \%$ & $73.98 \%$ & $53.29 \%$ & $67.00 \%$ \\
\hline BEL & $0.44 \%$ & $2.14 \%$ & $0.81 \%$ & $0.56 \%$ & $1.24 \%$ & $74.40 \%$ & $59.89 \%$ & $68.12 \%$ \\
\hline POL & $0.47 \%$ & $2.30 \%$ & $0.77 \%$ & $0.56 \%$ & $1.24 \%$ & $72.23 \%$ & $49.66 \%$ & $64.60 \%$ \\
\hline ITA & $0.44 \%$ & $2.13 \%$ & $0.83 \%$ & $0.55 \%$ & $1.22 \%$ & $60.68 \%$ & $48.83 \%$ & $56.53 \%$ \\
\hline NLD & $0.47 \%$ & $2.29 \%$ & $0.69 \%$ & $0.54 \%$ & $1.19 \%$ & $72.05 \%$ & $45.39 \%$ & $59.77 \%$ \\
\hline TUR & $0.32 \%$ & $1.58 \%$ & $1.08 \%$ & $0.51 \%$ & $1.13 \%$ & $40.60 \%$ & $59.00 \%$ & $46.10 \%$ \\
\hline $\mathrm{CZE}$ & $0.40 \%$ & $1.97 \%$ & $0.76 \%$ & $0.49 \%$ & $1.08 \%$ & $75.69 \%$ & $60.18 \%$ & $72.01 \%$ \\
\hline LUX & $0.46 \%$ & $2.26 \%$ & $0.60 \%$ & $0.48 \%$ & $1.06 \%$ & $86.06 \%$ & $42.98 \%$ & $47.30 \%$ \\
\hline DNK & $0.44 \%$ & $2.17 \%$ & $0.56 \%$ & $0.47 \%$ & $1.03 \%$ & $69.89 \%$ & $38.09 \%$ & $50.05 \%$ \\
\hline LTU & $0.57 \%$ & $2.80 \%$ & $0.44 \%$ & $0.45 \%$ & $1.00 \%$ & $78.92 \%$ & $28.26 \%$ & $45.45 \%$ \\
\hline BGR & $0.35 \%$ & $1.73 \%$ & $0.63 \%$ & $0.45 \%$ & $0.99 \%$ & $47.00 \%$ & $37.70 \%$ & $42.83 \%$ \\
\hline AUT & $0.37 \%$ & $1.80 \%$ & $0.62 \%$ & $0.45 \%$ & $0.99 \%$ & $72.71 \%$ & $50.68 \%$ & $64.16 \%$ \\
\hline CYP & $0.36 \%$ & $1.75 \%$ & $0.52 \%$ & $0.41 \%$ & $0.91 \%$ & $44.87 \%$ & $28.53 \%$ & $32.81 \%$ \\
\hline GBR & $0.30 \%$ & $1.46 \%$ & $0.58 \%$ & $0.41 \%$ & $0.90 \%$ & $45.58 \%$ & $38.03 \%$ & $41.22 \%$ \\
\hline GRC & $0.36 \%$ & $1.75 \%$ & $0.48 \%$ & $0.39 \%$ & $0.86 \%$ & $45.04 \%$ & $28.27 \%$ & $32.67 \%$ \\
\hline RUS & $0.20 \%$ & $0.99 \%$ & $0.57 \%$ & $0.36 \%$ & $0.81 \%$ & $30.71 \%$ & $33.99 \%$ & $32.68 \%$ \\
\hline DEU & $0.30 \%$ & $1.46 \%$ & $0.43 \%$ & $0.34 \%$ & $0.75 \%$ & $60.02 \%$ & $42.55 \%$ & $55.85 \%$ \\
\hline FRA & $0.29 \%$ & $1.42 \%$ & $0.44 \%$ & $0.34 \%$ & $0.74 \%$ & $58.87 \%$ & $39.88 \%$ & $52.89 \%$ \\
\hline IRL & $0.14 \%$ & $0.69 \%$ & $0.22 \%$ & $0.17 \%$ & $0.37 \%$ & $23.79 \%$ & $15.96 \%$ & $19.62 \%$ \\
\hline EU 27 Mean & $0.46 \%$ & $2.23 \%$ & $0.75 \%$ & $0.55 \%$ & $1.21 \%$ & $63.66 \%$ & $45.71 \%$ & $54.65 \%$ \\
\hline EU 27 Median & $0.46 \%$ & $2.26 \%$ & $0.76 \%$ & $0.55 \%$ & $1.22 \%$ & $67.76 \%$ & $45.39 \%$ & $56.52 \%$ \\
\hline EU 27 & $0.38 \%$ & $1.86 \%$ & $0.64 \%$ & $0.46 \%$ & $1.02 \%$ & $62.03 \%$ & $43.92 \%$ & $54.96 \%$ \\
\hline
\end{tabular}


TABle A6

Average Tariff Equivalents due to Schengen, by Country

\begin{tabular}{|c|c|c|c|c|c|c|}
\hline \multirow[t]{2}{*}{ Country } & \multicolumn{3}{|c|}{$\begin{array}{l}\text { Average Tariff Equivalents } \\
\qquad(\sigma=6)\end{array}$} & \multicolumn{3}{|c|}{$\begin{array}{l}\text { Share of Schengen Trade } \\
\text { in Total Trade }\end{array}$} \\
\hline & Goods & Services & Total Trade & Goods & Services & Total Trade \\
\hline EST & $0.88 \%$ & $1.19 \%$ & $1.03 \%$ & $68.87 \%$ & $52.50 \%$ & $61.04 \%$ \\
\hline LVA & $0.90 \%$ & $1.08 \%$ & $1.01 \%$ & $67.76 \%$ & $50.20 \%$ & $57.51 \%$ \\
\hline FIN & $0.93 \%$ & $1.11 \%$ & $0.99 \%$ & $52.29 \%$ & $43.26 \%$ & $49.35 \%$ \\
\hline MLT & $0.59 \%$ & $1.14 \%$ & $0.92 \%$ & $51.16 \%$ & $59.95 \%$ & $56.52 \%$ \\
\hline PRT & $0.90 \%$ & $0.96 \%$ & $0.92 \%$ & $79.40 \%$ & $58.41 \%$ & $70.27 \%$ \\
\hline HUN & $0.84 \%$ & $1.02 \%$ & $0.90 \%$ & $73.13 \%$ & $55.39 \%$ & $67.53 \%$ \\
\hline SVK & $0.74 \%$ & $0.95 \%$ & $0.80 \%$ & $79.37 \%$ & $69.53 \%$ & $76.60 \%$ \\
\hline SWE & $0.81 \%$ & $0.72 \%$ & $0.77 \%$ & $60.83 \%$ & $36.08 \%$ & $50.36 \%$ \\
\hline ESP & $0.66 \%$ & $0.93 \%$ & $0.77 \%$ & $67.12 \%$ & $58.03 \%$ & $63.36 \%$ \\
\hline ROM & $0.68 \%$ & $0.79 \%$ & $0.73 \%$ & $57.13 \%$ & $42.77 \%$ & $50.03 \%$ \\
\hline SVN & $0.71 \%$ & $0.78 \%$ & $0.73 \%$ & $73.98 \%$ & $53.29 \%$ & $67.00 \%$ \\
\hline BEL & $0.61 \%$ & $0.80 \%$ & $0.69 \%$ & $74.40 \%$ & $59.89 \%$ & $68.12 \%$ \\
\hline POL & $0.66 \%$ & $0.77 \%$ & $0.69 \%$ & $72.23 \%$ & $49.66 \%$ & $64.60 \%$ \\
\hline ITA & $0.61 \%$ & $0.83 \%$ & $0.69 \%$ & $60.68 \%$ & $48.83 \%$ & $56.53 \%$ \\
\hline NLD & $0.66 \%$ & $0.69 \%$ & $0.67 \%$ & $72.05 \%$ & $45.39 \%$ & $59.77 \%$ \\
\hline TUR & $0.45 \%$ & $1.07 \%$ & $0.63 \%$ & $40.60 \%$ & $59.00 \%$ & $46.10 \%$ \\
\hline CZE & $0.57 \%$ & $0.75 \%$ & $0.61 \%$ & $75.69 \%$ & $60.18 \%$ & $72.01 \%$ \\
\hline LUX & $0.65 \%$ & $0.59 \%$ & $0.60 \%$ & $86.06 \%$ & $42.98 \%$ & $47.30 \%$ \\
\hline DNK & $0.62 \%$ & $0.55 \%$ & $0.58 \%$ & $69.89 \%$ & $38.09 \%$ & $50.05 \%$ \\
\hline LTU & $0.80 \%$ & $0.44 \%$ & $0.56 \%$ & $78.92 \%$ & $28.26 \%$ & $45.45 \%$ \\
\hline BGR & $0.50 \%$ & $0.63 \%$ & $0.55 \%$ & $47.00 \%$ & $37.70 \%$ & $42.83 \%$ \\
\hline AUT & $0.52 \%$ & $0.61 \%$ & $0.55 \%$ & $72.71 \%$ & $50.68 \%$ & $64.16 \%$ \\
\hline CYP & $0.50 \%$ & $0.51 \%$ & $0.51 \%$ & $44.87 \%$ & $28.53 \%$ & $32.81 \%$ \\
\hline GBR & $0.42 \%$ & $0.57 \%$ & $0.51 \%$ & $45.58 \%$ & $38.03 \%$ & $41.22 \%$ \\
\hline GRC & $0.50 \%$ & $0.48 \%$ & $0.48 \%$ & $45.04 \%$ & $28.27 \%$ & $32.67 \%$ \\
\hline RUS & $0.28 \%$ & $0.57 \%$ & $0.45 \%$ & $30.71 \%$ & $33.99 \%$ & $32.68 \%$ \\
\hline DEU & $0.42 \%$ & $0.43 \%$ & $0.42 \%$ & $60.02 \%$ & $42.55 \%$ & $55.85 \%$ \\
\hline FRA & $0.41 \%$ & $0.43 \%$ & $0.42 \%$ & $58.87 \%$ & $39.88 \%$ & $52.89 \%$ \\
\hline IRL & $0.20 \%$ & $0.22 \%$ & $0.21 \%$ & $23.79 \%$ & $15.96 \%$ & $19.62 \%$ \\
\hline EU 27 Mean & $0.64 \%$ & $0.74 \%$ & $0.68 \%$ & $63.66 \%$ & $45.71 \%$ & $54.65 \%$ \\
\hline EU 27 Median & $0.65 \%$ & $0.75 \%$ & $0.69 \%$ & $67.76 \%$ & $45.39 \%$ & $56.52 \%$ \\
\hline EU 27 & $0.53 \%$ & $0.63 \%$ & $0.57 \%$ & $62.03 \%$ & $43.92 \%$ & $54.96 \%$ \\
\hline
\end{tabular}

Note: Sorted by Total AVTE in descending order. AVTEs have been calculated dependent on each country's trade volumes of goods and services trade across the number of Schengen borders. The counterfactual trade volumes have been calculated respective of estimated Schengen effects from the gravity estimation. AVTEs result from the difference in counterfactual (cf) to observed (obs) trade, assuming $\sigma=6$ : $\left(X^{c f} / X^{o b s}\right)^{(1 / \sigma)}-1$. 
TABLE A7

The Impact of Schengen on Bilateral Exports, including all Sectors (1995 - 2011)

\begin{tabular}{|c|c|c|c|c|c|c|c|}
\hline \multirow[t]{3}{*}{ Dep. var.: } & \multicolumn{7}{|c|}{ Bilateral Exports } \\
\hline & \multicolumn{2}{|c|}{ Total Trade } & \multicolumn{3}{|l|}{ Goods } & \multicolumn{2}{|l|}{ Services } \\
\hline & (1) & (2) & (3) & (4) & (5) & (6) & (7) \\
\hline Schengen $_{i j, t}$ & $\begin{array}{c}0.061^{* * *} \\
(0.01)\end{array}$ & $\begin{array}{l}0.007 \\
(0.01)\end{array}$ & $\begin{array}{c}0.109^{* * * *} \\
(0.02)\end{array}$ & $\begin{array}{c}0.035^{* * *} \\
(0.01)\end{array}$ & $\begin{array}{c}0.034^{* * *} \\
(0.01)\end{array}$ & $\begin{array}{c}0.067^{* * *} \\
(0.02)\end{array}$ & $\begin{array}{l}0.040^{*} \\
(0.02)\end{array}$ \\
\hline Both $\mathrm{EU}_{i j, t}$ & & $\begin{array}{c}0.592^{* * *} \\
(0.07)\end{array}$ & & $\begin{array}{c}0.744^{* * * *} \\
(0.07)\end{array}$ & $\begin{array}{c}0.475^{* * *} \\
(0.10)\end{array}$ & & $\begin{array}{c}0.335^{* * *} \\
(0.08)\end{array}$ \\
\hline 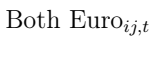 & & $\begin{array}{c}0.054^{* *} \\
(0.02)\end{array}$ & & $\begin{array}{c}0.147^{* * * *} \\
(0.03)\end{array}$ & $\begin{array}{c}0.152^{* * *} \\
(0.03)\end{array}$ & & $\begin{array}{l}0.084^{*} \\
(0.04)\end{array}$ \\
\hline Other $\mathrm{RTA}_{i j, t}$ & & $\begin{array}{c}0.236^{* * *} \\
(0.06)\end{array}$ & & $\begin{array}{c}0.268^{* * *} \\
(0.06)\end{array}$ & $\begin{array}{c}0.268^{* * *} \\
(0.07)\end{array}$ & & $\begin{array}{c}0.184^{* *} \\
(0.07)\end{array}$ \\
\hline $\mathrm{MFN}_{i j, t}$ & & & & & $\begin{array}{c}-2.342^{* * *} \\
(0.50)\end{array}$ & & \\
\hline
\end{tabular}

Note: $* * *, * *, *$ denote significance at the $1 \%, 5 \%, 10 \%$ level, respectively. Robust clustered standard errors reported in parentheses. Pair as well as year specific importer and exporter fixed effects included but not reported. Number of observations: 27,200.

\section{TABLE A8}

Endogeneity of Schengen and Bilateral Exports, excluding Gas, Fuel, Coke, Mining \& Quarrying and the 3 Most Important Trade Partners (1995 - 2011)

\begin{tabular}{|c|c|c|c|c|c|c|c|}
\hline \multirow[t]{3}{*}{ Dep. var.: } & \multicolumn{7}{|c|}{ Bilateral Exports } \\
\hline & \multicolumn{2}{|c|}{ Total Trade } & \multicolumn{3}{|l|}{ Goods } & \multicolumn{2}{|l|}{ Services } \\
\hline & (1) & (2) & (3) & (4) & (5) & (6) & $(7)$ \\
\hline Schengen $_{i j, t}$ & $\begin{array}{c}0.041^{* * *} \\
(0.01)\end{array}$ & $\begin{array}{l}-0.003 \\
(0.01)\end{array}$ & $\begin{array}{c}0.085^{* * *} \\
(0.01)\end{array}$ & $\begin{array}{c}0.017^{* *} \\
(0.01)\end{array}$ & $\begin{array}{c}0.017^{* *} \\
(0.01)\end{array}$ & $\begin{array}{c}0.075^{* * *} \\
(0.02)\end{array}$ & $\begin{array}{c}0.043^{* *} \\
(0.02)\end{array}$ \\
\hline Both $\mathrm{EU}_{i j, t}$ & & $\begin{array}{c}0.607^{* * *} \\
(0.07)\end{array}$ & & $\begin{array}{c}0.710^{* * *} \\
(0.07)\end{array}$ & $\begin{array}{c}0.493^{* * *} \\
(0.09)\end{array}$ & & $\begin{array}{c}0.342^{* * *} \\
(0.07)\end{array}$ \\
\hline Both Euro $_{i j, t}$ & & $\begin{array}{l}-0.026 \\
(0.03)\end{array}$ & & $\begin{array}{c}0.067^{* *} \\
(0.03)\end{array}$ & $\begin{array}{c}0.071^{* *} \\
(0.03)\end{array}$ & & $\begin{array}{l}0.087^{*} \\
(0.05)\end{array}$ \\
\hline Other $\mathrm{RTA}_{i j, t}$ & & $\begin{array}{c}0.250^{* * *} \\
(0.07)\end{array}$ & & $\begin{array}{c}0.170^{* * *} \\
(0.06)\end{array}$ & $\begin{array}{c}0.163^{* * *} \\
(0.06)\end{array}$ & & $\begin{array}{c}0.144^{* *} \\
(0.06)\end{array}$ \\
\hline $\mathrm{MFN}_{i j, t}$ & & & & & $\begin{array}{c}-1.818^{* * *} \\
(0.50)\end{array}$ & & \\
\hline
\end{tabular}

Note: $* * *, * *, *$ denote significance at the $1 \%, 5 \%, 10 \%$ level, respectively. Robust clustered standard errors reported in parentheses. Pair as well as year specific importer and exporter fixed effects included but not reported. All specifications exclude the 3 most important trade partners of each country. Number of observations: 25,160 . 


\section{TABle A9}

The Impact of Schengen on Bilateral Exports, excluding Gas, Fuel, Coke, Mining \& Quarrying, European Sample (1995 - 2011)

\begin{tabular}{|c|c|c|c|c|c|c|c|}
\hline \multirow[t]{3}{*}{ Dep. var.: } & \multicolumn{7}{|c|}{ Bilateral Exports } \\
\hline & \multicolumn{2}{|c|}{ Total Trade } & \multicolumn{3}{|l|}{ Goods } & \multicolumn{2}{|l|}{ Services } \\
\hline & (1) & (2) & (3) & (4) & (5) & (6) & (7) \\
\hline Schengen $_{i j, t}$ & $\begin{array}{c}0.061^{* * * *} \\
(0.01)\end{array}$ & $\begin{array}{l}0.005 \\
(0.01)\end{array}$ & $\begin{array}{c}0.120^{* * *} \\
(0.02)\end{array}$ & $\begin{array}{c}0.034^{* * * *} \\
(0.01)\end{array}$ & $\begin{array}{c}0.034^{* * *} \\
(0.01)\end{array}$ & $\begin{array}{c}0.081^{* * *} \\
(0.02)\end{array}$ & $\begin{array}{c}0.057^{* * * *} \\
(0.02)\end{array}$ \\
\hline Both $\mathrm{EU}_{i j, t}$ & & $\begin{array}{c}0.993^{* * * *} \\
(0.10)\end{array}$ & & $\begin{array}{c}1.380^{* * * *} \\
(0.10)\end{array}$ & $\begin{array}{c}1.423^{* * *} \\
(0.10)\end{array}$ & & $\begin{array}{c}0.471^{* * * *} \\
(0.16)\end{array}$ \\
\hline 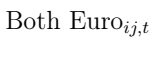 & & $\begin{array}{l}0.033 \\
(0.02)\end{array}$ & & $\begin{array}{c}0.155^{* * * *} \\
(0.03)\end{array}$ & $\begin{array}{c}0.155^{* * *} \\
(0.03)\end{array}$ & & $\begin{array}{c}0.081^{* *} \\
(0.04)\end{array}$ \\
\hline Other $\mathrm{RTA}_{i j, t}$ & & $\begin{array}{c}0.617^{* * * *} \\
(0.10)\end{array}$ & & $\begin{array}{c}0.843^{* * *} \\
(0.09)\end{array}$ & $\begin{array}{c}0.843^{* * *} \\
(0.09)\end{array}$ & & $\begin{array}{c}0.342^{* *} \\
(0.16)\end{array}$ \\
\hline $\mathrm{MFN}_{i j, t}$ & & & & & $\begin{array}{l}0.361 \\
(0.36)\end{array}$ & & \\
\hline
\end{tabular}

Note: ${ }^{* * *}, * *, *$ denote significance at the $1 \%, 5 \%, 10 \%$ level, respectively. Robust clustered standard errors reported in parentheses. Pair as well as year specific importer and exporter fixed effects included but not reported. Number of observations: 14,297.

TABle A10

The Impact of Schengen on Bilateral Exports, excluding Gas, Fuel, Coke, Mining \& Quarrying, Intercontinental Trade with one Schengen Border

(1995 - 2011)

\begin{tabular}{|c|c|c|c|c|c|c|c|}
\hline \multirow{3}{*}{ Dep. var.: } & \multicolumn{7}{|c|}{ Bilateral Exports } \\
\hline & \multicolumn{2}{|c|}{ Total Trade } & \multicolumn{3}{|l|}{ Goods } & \multicolumn{2}{|l|}{ Services } \\
\hline & (1) & (2) & (3) & (4) & (5) & (6) & (7) \\
\hline Schengen $_{i j, t}$ & $\begin{array}{c}0.072^{* * *} \\
(0.01)\end{array}$ & $\begin{array}{c}0.024^{* * *} \\
(0.01)\end{array}$ & $\begin{array}{c}0.122^{* * *} \\
(0.02)\end{array}$ & $\begin{array}{c}0.050^{* * * *} \\
(0.01)\end{array}$ & $\begin{array}{c}0.048^{* * *} \\
(0.01)\end{array}$ & $\begin{array}{c}0.094^{* * *} \\
(0.02)\end{array}$ & $\begin{array}{c}0.073^{* * *} \\
(0.02)\end{array}$ \\
\hline Both $\mathrm{EU}_{i j, t}$ & & $\begin{array}{c}0.594^{* * *} \\
(0.07)\end{array}$ & & $\begin{array}{c}0.779^{* * *} \\
(0.07)\end{array}$ & $\begin{array}{c}0.508^{* * *} \\
(0.11)\end{array}$ & & $\begin{array}{c}0.298^{* * *} \\
(0.09)\end{array}$ \\
\hline 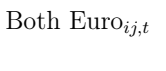 & & $\begin{array}{l}0.021 \\
(0.02)\end{array}$ & & $\begin{array}{c}0.129^{* * * *} \\
(0.03)\end{array}$ & $\begin{array}{c}0.135^{* * *} \\
(0.03)\end{array}$ & & $\begin{array}{l}0.074^{*} \\
(0.04)\end{array}$ \\
\hline Other $\mathrm{RTA}_{i j, t}$ & & $\begin{array}{c}0.249^{* * *} \\
(0.07)\end{array}$ & & $\begin{array}{c}0.293^{* * * *} \\
(0.06)\end{array}$ & $\begin{array}{c}0.301^{* * *} \\
(0.07)\end{array}$ & & $\begin{array}{c}0.181^{* *} \\
(0.07)\end{array}$ \\
\hline $\mathrm{MFN}_{i j, t}$ & $(0.12)$ & $(0.15)$ & $(0.25)$ & $(0.29)$ & $\begin{array}{c}-2.433^{* * *} \\
(0.57) \\
(0.35)\end{array}$ & $(0.11)$ & $(0.14)$ \\
\hline
\end{tabular}

Note: $* * *, * *, *$ denote significance at the 1\%,5\%,10\% level, respectively. Robust clustered standard errors reported in parentheses. Pair as well as year specific importer and exporter fixed effects included but not reported. Number of observations: 27,200. 
TABle A11

The Impact of Schengen on Bilateral Exports, excluding Gas, Fuel, Coke, Mining \& Quarrying, Dummy (1995 - 2011)

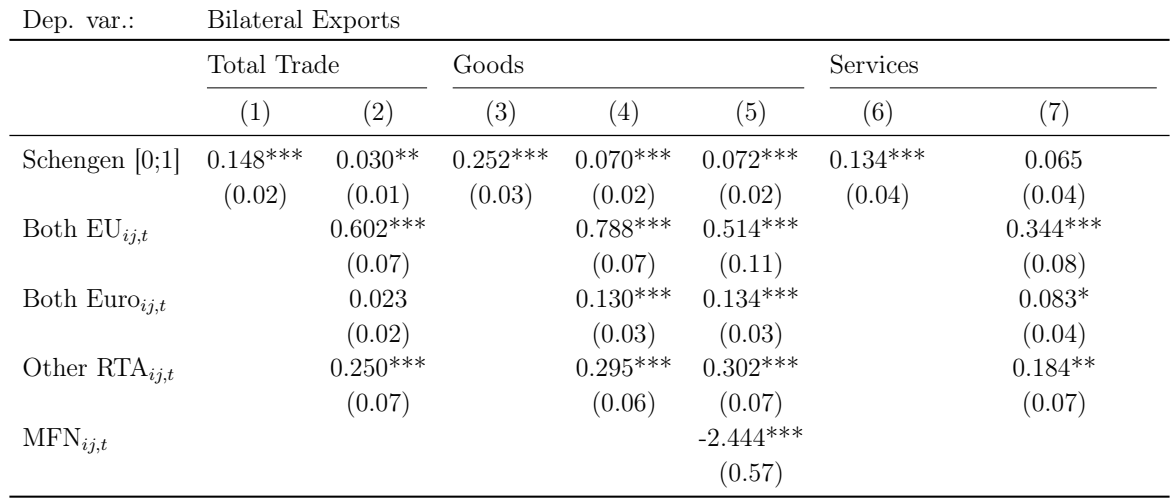

Note: $* * *, * *, *$ denote significance at the 1\%,5\%,10\% level, respectively. Robust clustered standard errors reported in parentheses. Pair as well as year specific importer and exporter fixed effects included but not reported. Number of observations: 27,200.

TABLE A12

The Impact of Schengen on Bilateral Exports, excluding Gas, Fuel, Coke, Mining \& Quarrying, Indicator (1995 - 2011)

\begin{tabular}{|c|c|c|c|c|c|c|c|}
\hline \multirow[t]{3}{*}{ Dep. var.: } & \multicolumn{7}{|c|}{ Bilateral Exports } \\
\hline & \multicolumn{2}{|c|}{ Total Trade } & \multicolumn{3}{|l|}{ Goods } & \multicolumn{2}{|l|}{ Services } \\
\hline & (1) & $(2)$ & (3) & $(4)$ & $(5)$ & (6) & $(7)$ \\
\hline Schengen $[0 ; 0.5 ; 1]$ & $\begin{array}{c}0.306^{* * *} \\
(0.03)\end{array}$ & $\begin{array}{c}0.161^{* * *} \\
(0.03)\end{array}$ & $\begin{array}{c}0.493^{* * *} \\
(0.05)\end{array}$ & $\begin{array}{c}0.254^{* * *} \\
(0.03)\end{array}$ & $\begin{array}{c}0.247^{* * *} \\
(0.03)\end{array}$ & $\begin{array}{c}0.346^{* * *} \\
(0.05)\end{array}$ & $\begin{array}{c}0.300^{* * *} \\
(0.06)\end{array}$ \\
\hline Both $\mathrm{EU}_{i j, t}$ & & $\begin{array}{c}0.559^{* * *} \\
(0.07)\end{array}$ & & $\begin{array}{c}0.738^{* * *} \\
(0.07)\end{array}$ & $\begin{array}{c}0.469^{* * *} \\
(0.11)\end{array}$ & & $\begin{array}{c}0.260^{* * *} \\
(0.09)\end{array}$ \\
\hline Both $\operatorname{Euro}_{i j, t}$ & & $\begin{array}{l}0.011 \\
(0.02)\end{array}$ & & $\begin{array}{c}0.118^{* * *} \\
(0.03)\end{array}$ & $\begin{array}{c}0.124^{* * *} \\
(0.03)\end{array}$ & & $\begin{array}{l}0.065 \\
(0.04)\end{array}$ \\
\hline Other $\mathrm{RTA}_{i j, t}$ & & $\begin{array}{c}0.247^{* * *} \\
(0.07)\end{array}$ & & $\begin{array}{c}0.291^{* * *} \\
(0.06)\end{array}$ & $\begin{array}{c}0.299^{* * *} \\
(0.07)\end{array}$ & & $\begin{array}{c}0.177^{* *} \\
(0.07)\end{array}$ \\
\hline $\mathrm{MFN}_{i j, t}$ & & & & & $\begin{array}{c}-2.426^{* * *} \\
(0.57)\end{array}$ & & \\
\hline
\end{tabular}




\section{TABLE A13}

The Impact of Schengen on Bilateral Exports, excluding Gas, Fuel, Coke, Mining \& Quarrying, Pooled over Sectors (1995 - 2011)

\begin{tabular}{|c|c|c|c|c|c|c|c|}
\hline \multirow[t]{3}{*}{ Dep. var.: } & \multicolumn{7}{|c|}{ Bilateral Exports } \\
\hline & \multicolumn{2}{|c|}{ Total Trade } & \multicolumn{3}{|l|}{ Goods } & \multicolumn{2}{|l|}{ Services } \\
\hline & $(1)$ & $(2)$ & $(3)$ & (4) & $(5)$ & (6) & $(7)$ \\
\hline Schengen $_{i j, t}$ & $\begin{array}{c}0.054^{* * *} \\
(0.01)\end{array}$ & $\begin{array}{c}0.0003 \\
(0.01)\end{array}$ & $\begin{array}{c}0.106^{* * *} \\
(0.01)\end{array}$ & $\begin{array}{c}0.026^{* * *} \\
(0.01)\end{array}$ & $\begin{array}{c}0.026^{* * *} \\
(0.01)\end{array}$ & $\begin{array}{c}0.067^{* * *} \\
(0.02)\end{array}$ & $\begin{array}{c}0.040^{*} \\
(0.02)\end{array}$ \\
\hline Both $\mathrm{EU}_{i j, t}$ & & $\begin{array}{c}0.617^{* * *} \\
(0.08)\end{array}$ & & $\begin{array}{c}0.800^{* * *} \\
(0.10)\end{array}$ & $\begin{array}{c}0.527^{* * *} \\
(0.11)\end{array}$ & & $\begin{array}{c}0.335^{* * *} \\
(0.08)\end{array}$ \\
\hline Both Euro $_{i j, t}$ & & $\begin{array}{l}0.030 \\
(0.02)\end{array}$ & & $\begin{array}{c}0.137^{* * *} \\
(0.03)\end{array}$ & $\begin{array}{c}0.142^{* * *} \\
(0.03)\end{array}$ & & $\begin{array}{c}0.084^{*} \\
(0.04)\end{array}$ \\
\hline Other $\mathrm{RTA}_{i j, t}$ & & $\begin{array}{c}0.250^{* * *} \\
(0.08)\end{array}$ & & $\begin{array}{c}0.294^{* * *} \\
(0.09)\end{array}$ & $\begin{array}{c}0.302^{* * *} \\
(0.10)\end{array}$ & & $\begin{array}{c}0.184^{* *} \\
(0.07)\end{array}$ \\
\hline $\mathrm{MFN}_{i j, t}$ & & & & & $\begin{array}{c}-2.443^{* * *} \\
(0.40)\end{array}$ & & \\
\hline Observations & 897,600 & 897,600 & 380,800 & 380,800 & 380,800 & 514,539 & 514,539 \\
\hline
\end{tabular}

\section{TABLe A14}

The Impact of Schengen on Bilateral Exports, excluding Gas, Fuel, Coke, Mining \& Quarrying, Baier and Bergstrand (2009) MR-Terms (1995 - 2011)

Dependent Variable: Bilateral Exports

\begin{tabular}{|c|c|c|c|c|c|c|c|}
\hline & \multicolumn{2}{|c|}{ Total Trade } & \multicolumn{3}{|l|}{ Goods } & \multicolumn{2}{|l|}{ Services } \\
\hline & (1) & (2) & (3) & (4) & (5) & (6) & (7) \\
\hline Schengen $_{i j, t}$ & $\begin{array}{c}0.060^{* * *} \\
(0.01)\end{array}$ & $\begin{array}{l}0.005 \\
(0.01)\end{array}$ & $\begin{array}{c}0.118^{* * *} \\
(0.02)\end{array}$ & $\begin{array}{c}0.037^{* * *} \\
(0.01)\end{array}$ & $\begin{array}{c}0.038^{* * *} \\
(0.01)\end{array}$ & $\begin{array}{c}0.060^{* * *} \\
(0.02)\end{array}$ & $\begin{array}{l}0.034 \\
(0.02)\end{array}$ \\
\hline Both $\mathrm{EU}_{i j, t}$ & & $\begin{array}{c}0.651^{* * *} \\
(0.09)\end{array}$ & & $\begin{array}{c}0.818^{* * *} \\
(0.09)\end{array}$ & $\begin{array}{c}0.653^{* * *} \\
(0.11)\end{array}$ & & $\begin{array}{c}0.330^{* * *} \\
(0.09)\end{array}$ \\
\hline Both Euro $_{i j, t}$ & & $\begin{array}{l}0.029 \\
(0.03)\end{array}$ & & $\begin{array}{c}0.124^{* * *} \\
(0.03)\end{array}$ & $\begin{array}{c}0.126^{* * *} \\
(0.03)\end{array}$ & & $\begin{array}{l}0.079^{*} \\
(0.05)\end{array}$ \\
\hline Other $\mathrm{RTA}_{i j, t}$ & & $\begin{array}{c}0.275^{* * *} \\
(0.08)\end{array}$ & & $\begin{array}{c}0.322^{* * *} \\
(0.08)\end{array}$ & $\begin{array}{c}0.313^{* * *} \\
(0.08)\end{array}$ & & $\begin{array}{c}0.168^{* *} \\
(0.08)\end{array}$ \\
\hline $\mathrm{MFN}_{i j, t}$ & & & & & $\begin{array}{c}-1.350^{* *} \\
(0.55)\end{array}$ & & \\
\hline $\ln$ Supply $_{i, t}$ & $\begin{array}{c}0.651^{* * *} \\
(0.07)\end{array}$ & $\begin{array}{c}0.649^{* * *} \\
(0.07)\end{array}$ & $\begin{array}{c}0.740^{* * *} \\
(0.07)\end{array}$ & $\begin{array}{c}0.736^{* * *} \\
(0.07)\end{array}$ & $\begin{array}{c}0.751^{* * *} \\
(0.06)\end{array}$ & $\begin{array}{c}0.554^{* * *} \\
(0.09)\end{array}$ & $\begin{array}{c}0.550^{* * *} \\
(0.09)\end{array}$ \\
\hline ln Demand $_{j, t}$ & $\begin{array}{c}0.438^{* * *} \\
(0.07)\end{array}$ & $\begin{array}{c}0.439^{* * *} \\
(0.07)\end{array}$ & $\begin{array}{c}0.407^{* * *} \\
(0.08)\end{array}$ & $\begin{array}{c}0.401^{* * *} \\
(0.08)\end{array}$ & $\begin{array}{c}0.394^{* * *} \\
(0.07)\end{array}$ & $\begin{array}{c}0.445^{* * *} \\
(0.09)\end{array}$ & $\begin{array}{c}0.453^{* * *} \\
(0.09)\end{array}$ \\
\hline
\end{tabular}

Note: ${ }^{* * *},{ }^{* *}, *$, denote significance at the $1 \%, 5 \%$, and $10 \%$ level, respectively. Robust clustered standard errors reported in parentheses. Pair, country, and time fixed effects included but not reported. All specifications include Baier and Bergstrand (2009) multilateral resistance terms for all trade costs. Number of observations: 25,857 . 
TABLE A15

The Impact of Schengen on Bilateral Exports, excluding Gas, Fuel, Coke, Mining \& Quarrying, PPML without bilateral fixed effects

$(1995-2011)$

\begin{tabular}{|c|c|c|c|c|c|c|c|}
\hline \multirow{3}{*}{ Dep. var.: } & \multicolumn{2}{|c|}{ Total Trade } & \multicolumn{3}{|l|}{ Goods } & \multicolumn{2}{|l|}{ Services } \\
\hline & & & & & & & \\
\hline & (1) & (2) & (3) & (4) & (5) & (6) & (7) \\
\hline Schengen $_{i j, t}$ & $\begin{array}{c}-0.437^{* * *} \\
(0.06)\end{array}$ & $\begin{array}{l}-0.130 \\
(0.08)\end{array}$ & $\begin{array}{c}-0.196^{* * * *} \\
(0.05)\end{array}$ & $\begin{array}{l}-0.084 \\
(0.07)\end{array}$ & $\begin{array}{c}-0.139^{* *} \\
(0.06)\end{array}$ & $\begin{array}{c}-0.655^{* * *} \\
(0.09)\end{array}$ & $\begin{array}{l}-0.148 \\
(0.09)\end{array}$ \\
\hline Both $\mathrm{EU}_{i j, t}$ & & $\begin{array}{c}-1.098^{* * *} \\
(0.19)\end{array}$ & & $\begin{array}{c}-0.496^{* * *} \\
(0.16)\end{array}$ & $\begin{array}{c}-0.923^{* * *} \\
(0.15)\end{array}$ & & $\begin{array}{c}-1.661^{* * *} \\
(0.22)\end{array}$ \\
\hline 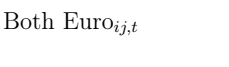 & & $\begin{array}{c}0.299^{* * * *} \\
(0.12)\end{array}$ & & $\begin{array}{c}0.212^{* *} \\
(0.09)\end{array}$ & $\begin{array}{c}0.252^{* * *} \\
(0.09)\end{array}$ & & $\begin{array}{l}0.277 \\
(0.19)\end{array}$ \\
\hline Other $\mathrm{RTA}_{i j, t}$ & & $\begin{array}{c}-1.415^{* * *} \\
(0.16)\end{array}$ & & $\begin{array}{c}-0.975^{* * *} \\
(0.15)\end{array}$ & $\begin{array}{c}-0.449^{* *} \\
(0.20)\end{array}$ & & $\begin{array}{c}-2.376^{* * *} \\
(0.21)\end{array}$ \\
\hline $\mathrm{MFN}_{i j, t}$ & & & & & $\begin{array}{c}-8.873^{* * *} \\
(1.74)\end{array}$ & & \\
\hline ln Distance $_{i j}$ & $\begin{array}{c}-2.314^{* * *} \\
(0.06)\end{array}$ & $\begin{array}{c}-2.211^{* * *} \\
(0.06)\end{array}$ & $\begin{array}{c}-2.011^{* * *} \\
(0.06)\end{array}$ & $\begin{array}{c}-1.957^{* * *} \\
(0.06)\end{array}$ & $\begin{array}{c}-1.569^{* * *} \\
(0.06)\end{array}$ & $\begin{array}{c}-2.723^{* * *} \\
(0.09)\end{array}$ & $\begin{array}{c}-2.537^{* * *} * \\
(0.07)\end{array}$ \\
\hline Adjacency $_{i j}$ & $\begin{array}{c}-1.710^{* * *} \\
(0.12)\end{array}$ & $\begin{array}{c}-0.888^{* * *} \\
(0.15)\end{array}$ & $\begin{array}{c}-0.970^{* * *} \\
(0.10)\end{array}$ & $\begin{array}{c}-0.518^{* * *} \\
(0.16)\end{array}$ & $\begin{array}{c}-0.402^{* * *} \\
(0.14)\end{array}$ & $\begin{array}{c}-3.209^{* * *} \\
(0.26)\end{array}$ & $\begin{array}{c}-1.616^{* * *} \\
(0.19)\end{array}$ \\
\hline Common Language $_{i j}$ & $\begin{array}{l}0.064 \\
(0.25)\end{array}$ & $\begin{array}{c}0.279^{*} \\
(0.16)\end{array}$ & $\begin{array}{l}0.194 \\
(0.24)\end{array}$ & $\begin{array}{c}0.336^{* *} \\
(0.15)\end{array}$ & $\begin{array}{l}0.062 \\
(0.18)\end{array}$ & $\begin{array}{l}0.513^{*} \\
(0.26)\end{array}$ & $\begin{array}{c}0.686^{* * *} \\
(0.19)\end{array}$ \\
\hline Colony $_{i j}$ & $\begin{array}{l}0.318 \\
(0.21)\end{array}$ & $\begin{array}{l}0.039 \\
(0.18)\end{array}$ & $\begin{array}{l}0.142 \\
(0.18)\end{array}$ & $\begin{array}{c}-0.023 \\
(0.17)\end{array}$ & $\begin{array}{c}-0.135 \\
(0.17)\end{array}$ & $\begin{array}{c}0.713^{* * *} \\
(0.25)\end{array}$ & $\begin{array}{l}0.210 \\
(0.20)\end{array}$ \\
\hline Colony post $1945_{i j}$ & $\begin{array}{c}-0.877^{* *} \\
(0.43)\end{array}$ & $\begin{array}{c}-0.758^{*} \\
(0.40)\end{array}$ & $\begin{array}{c}-0.732^{*} \\
(0.43)\end{array}$ & $\begin{array}{l}-0.644 \\
(0.41)\end{array}$ & $\begin{array}{l}0.751^{*} \\
(0.43)\end{array}$ & $\begin{array}{c}-1.395^{* * *} \\
(0.52)\end{array}$ & $\begin{array}{c}-1.172^{* *} \\
(0.46)\end{array}$ \\
\hline Same Country $_{i j}$ & $\begin{array}{c}-0.757^{*} \\
(0.40)\end{array}$ & $\begin{array}{c}-0.504^{* *} \\
(0.22)\end{array}$ & $\begin{array}{c}-0.855^{* *} \\
(0.41)\end{array}$ & $\begin{array}{c}-0.618^{* * *} \\
(0.23)\end{array}$ & $\begin{array}{l}0.254 \\
(0.23)\end{array}$ & $\begin{array}{c}-1.207^{* *} \\
(0.56)\end{array}$ & $\begin{array}{c}-0.931^{*} \\
(0.50)\end{array}$ \\
\hline
\end{tabular}

Note: $* * *, * *, *$ denote significance at the $1 \%, 5 \%, 10 \%$ level, respectively. Robust clustered standard errors reported in parentheses. Pair as well as year specific importer and exporter fixed effects included but not reported. Number of observations: 27,200. 
TABLE A16

The Impact of Schengen on Bilateral Exports estimated in Bins (1995 - 2011)

Dep. var.: Bilateral Exports

\begin{tabular}{|c|c|c|c|c|}
\hline & \multirow{2}{*}{$\frac{\text { Total Trade }}{(1)}$} & \multicolumn{2}{|l|}{ Goods } & \multirow{2}{*}{$\frac{\text { Services }}{(4)}$} \\
\hline & & $(2)$ & (3) & \\
\hline Schengen Bin [1] & $\begin{array}{l}0.026 \\
(0.02)\end{array}$ & $\begin{array}{c}0.084^{* * *} \\
(0.02)\end{array}$ & $\begin{array}{c}0.089^{* * *} \\
(0.02)\end{array}$ & $\begin{array}{c}-0.048 \\
(0.06)\end{array}$ \\
\hline Schengen Bin [2] & $\begin{array}{l}0.036 \\
(0.02)\end{array}$ & $\begin{array}{c}0.113^{* * *} \\
(0.03)\end{array}$ & $\begin{array}{c}0.117^{* * *} \\
(0.03)\end{array}$ & $\begin{array}{l}-0.012 \\
(0.07)\end{array}$ \\
\hline Schengen Bin $[3 ; 8]$ & $\begin{array}{c}0.054^{*} \\
(0.03)\end{array}$ & $\begin{array}{c}0.140^{* * *} \\
(0.03)\end{array}$ & $\begin{array}{c}0.138^{* * *} \\
(0.03)\end{array}$ & $\begin{array}{c}0.169^{*} \\
(0.09)\end{array}$ \\
\hline Both EU & $\begin{array}{c}0.601^{* * *} \\
(0.07)\end{array}$ & $\begin{array}{c}0.778^{* * *} \\
(0.07)\end{array}$ & $\begin{array}{c}0.504^{* * *} \\
(0.11)\end{array}$ & $\begin{array}{c}0.331^{* * *} \\
(0.08)\end{array}$ \\
\hline Both Euro & $\begin{array}{l}0.024 \\
(0.02)\end{array}$ & $\begin{array}{c}0.129^{* * *} \\
(0.03)\end{array}$ & $\begin{array}{c}0.134^{* * *} \\
(0.03)\end{array}$ & $\begin{array}{c}0.088^{* *} \\
(0.04)\end{array}$ \\
\hline Other RTA & $\begin{array}{c}0.250^{* * *} \\
(0.07)\end{array}$ & $\begin{array}{c}0.294^{* * *} \\
(0.06)\end{array}$ & $\begin{array}{c}0.302^{* * *} \\
(0.07)\end{array}$ & $\begin{array}{c}0.184^{* *} \\
(0.07)\end{array}$ \\
\hline Tariff & & & $\begin{array}{c}-2.450^{* * *} \\
(0.57)\end{array}$ & \\
\hline
\end{tabular}




\section{ERIA Discussion Paper Series}

\begin{tabular}{|c|c|c|c|}
\hline No. & Author(s) & Title & Year \\
\hline $2016-36$ & $\begin{array}{l}\text { Gabriel FELBERMAYR } \\
\text { Jasmin GRÖSCHL } \\
\text { Thomas STEINWACHS }\end{array}$ & $\begin{array}{l}\text { The Trade Effect of Border Controls: } \\
\text { Evidence from the European Schengen } \\
\text { Agreement }\end{array}$ & $\begin{array}{r}\text { Mar } \\
2017\end{array}$ \\
\hline $2016-35$ & $\begin{array}{l}\text { Filipe R. CAMPANTE } \\
\text { and Davin CHOR }\end{array}$ & $\begin{array}{l}\text { "Just Do Your Job": Obedience, } \\
\text { Routine Tasks, and the Pattern of } \\
\text { Specialization }\end{array}$ & $\begin{array}{r}\text { Mar } \\
2017\end{array}$ \\
\hline $2016-34$ & $\begin{array}{l}\text { Isao KAMATA, Hitoshi } \\
\text { SATO, Kiyoyasu } \\
\text { TANAKA }\end{array}$ & $\begin{array}{l}\text { The Internationalisation of Firms and } \\
\text { Management Practices: A Survey of } \\
\text { Firms in Viet Nam }\end{array}$ & $\begin{array}{r}\text { Mar } \\
2017\end{array}$ \\
\hline $2016-33$ & Ikuo KUROIWA & $\begin{array}{l}\text { The Automotive Value Chain in } \\
\text { Thailand }\end{array}$ & $\begin{array}{r}\text { Mar } \\
2017\end{array}$ \\
\hline $2016-32$ & $\begin{array}{l}\text { Ikuo KUROIWA and } \\
\text { Kreingkrai } \\
\text { TECHAKANONT }\end{array}$ & $\begin{array}{l}\text { Formation of Automotive } \\
\text { Manufacturing Clusters in Thailand }\end{array}$ & $\begin{array}{c}\text { Feb } \\
2017\end{array}$ \\
\hline $2016-31$ & $\begin{array}{l}\text { Byeongwoo KANG, } \\
\text { Yukihito SATO and } \\
\text { Yasushi UEKI }\end{array}$ & $\begin{array}{l}\text { Mobility of Highly Skilled Retirees } \\
\text { from Japan to the Republic of Korea } \\
\text { and Taiwan }\end{array}$ & $\begin{array}{c}\text { Feb } \\
2017\end{array}$ \\
\hline 2016-30 & Stephen L. MAGIERA & $\begin{array}{l}\text { International Investment Agreements } \\
\text { and Investor-State Disputes: A Review } \\
\text { and Evaluation for Indonesia }\end{array}$ & $\begin{array}{c}\text { Jan } \\
2017\end{array}$ \\
\hline $2016-29$ & $\begin{array}{l}\text { Lili Yan ING, Miaojie YU } \\
\text { and Rui ZHANG }\end{array}$ & $\begin{array}{l}\text { Indonesia and China: Friends or Foes? } \\
\text { Quality Competition and Firm } \\
\text { Productivity }\end{array}$ & $\begin{array}{c}\text { Dec } \\
2016\end{array}$ \\
\hline $2016-28$ & $\begin{array}{l}\text { HAN Phoumin and } \\
\text { Shigeru KIMURA }\end{array}$ & $\begin{array}{l}\text { Analysis of Distributed Energy } \\
\text { Systems and Implications for } \\
\text { Electrification: The Case of ASEAN } \\
\text { Member States }\end{array}$ & $\begin{array}{c}\text { Dec } \\
2016\end{array}$ \\
\hline
\end{tabular}




\begin{tabular}{|c|c|c|c|}
\hline No. & Author(s) & Title & Year \\
\hline $2016-27$ & $\begin{array}{l}\text { Tomoo KIKUCHI and } \\
\text { Takehiro MASUMOTO }\end{array}$ & $\begin{array}{l}\text { Financial Reforms in Myanmar and } \\
\text { Japans' Engagement }\end{array}$ & $\begin{array}{l}\text { Nov } \\
2016\end{array}$ \\
\hline $2016-24$ & $\begin{array}{l}\text { Kazunobu } \\
\text { HAYAKAWA, Nuttawut } \\
\text { LAKSANAPANYAKUL, } \\
\text { Hiroshi MUKUNOKI and } \\
\text { Shujiro URATA }\end{array}$ & $\begin{array}{l}\text { Impact of Free Trade Agreement } \\
\text { Utilisation on Import Prices }\end{array}$ & $\begin{array}{l}\text { Aug } \\
2016\end{array}$ \\
\hline $2016-23$ & $\begin{array}{l}\text { Lili Yan ING, Olivier } \\
\text { CADOT and Janine } \\
\text { WALZ }\end{array}$ & $\begin{array}{l}\text { Transparency in Non-tariff Meausres: } \\
\text { An International Comparison }\end{array}$ & $\begin{array}{l}\text { Aug } \\
2016\end{array}$ \\
\hline $2016-22$ & $\begin{array}{l}\text { VO Tri Thanh and Cuong } \\
\text { Van NGUYEN }\end{array}$ & $\begin{array}{l}\text { Towards Responsive Regulatory } \\
\text { Management Systems: Country } \\
\text { Report for Viet Nam }\end{array}$ & $\begin{array}{l}\text { July } \\
2016\end{array}$ \\
\hline $2016-21$ & Gilberto M. LLANTO & $\begin{array}{l}\text { Towards a Requisite Regulatory } \\
\text { Management System: Philippines }\end{array}$ & $\begin{array}{l}\text { June } \\
2016\end{array}$ \\
\hline $2016-20$ & $\begin{array}{l}\text { Lili Yan ING and Olivier } \\
\text { CADOT }\end{array}$ & Facilitating ASEAN Trade in Goods & $\begin{array}{l}\text { June } \\
2016\end{array}$ \\
\hline 2016-19 & $\begin{array}{l}\text { Doan Thi Thanh HA, } \\
\text { Kozo KIYOTA, and } \\
\text { Kenta YAMANOUCHI }\end{array}$ & $\begin{array}{l}\text { Misallocation and Productivity: } \\
\text { The Case of Vietnamese } \\
\text { Manufacturing }\end{array}$ & $\begin{array}{l}\text { May } \\
2016\end{array}$ \\
\hline $2016-18$ & $\begin{array}{l}\text { Vangimalla R. REDDY, } \\
\text { Shardendu K. SINGH and } \\
\text { Venkatachalam } \\
\text { ANBUMOZHI }\end{array}$ & $\begin{array}{l}\text { Food Supply Chain Disruption due to } \\
\text { Natural Disasters: Entities, Risks, and } \\
\text { Strategies for Resilience }\end{array}$ & $\begin{array}{l}\text { May } \\
2016\end{array}$ \\
\hline $2016-17$ & $\begin{array}{l}\text { Arindam DAS-GUPTA, } \\
\text { Gemma B. ESTRADA, } \\
\text { Donghyun PARK }\end{array}$ & $\begin{array}{l}\text { Measuring Tax Administration } \\
\text { Effectiveness and its Impact on Tax } \\
\text { Revenue }\end{array}$ & $\begin{array}{l}\text { Apr } \\
2016\end{array}$ \\
\hline $2016-16$ & Naohiro YASHIRO & $\begin{array}{l}\text { Regulatory Coherence: The Case of } \\
\text { Japan }\end{array}$ & $\begin{array}{l}\text { Mar } \\
2016\end{array}$ \\
\hline
\end{tabular}




\begin{tabular}{|c|c|c|c|}
\hline No. & Author(s) & Title & Year \\
\hline $2016-15$ & $\begin{array}{l}\text { Song June KIM and Dae } \\
\text { Yong CHOI }\end{array}$ & $\begin{array}{l}\text { Regulatory Coherence: The Case of } \\
\text { the Republic of Korea }\end{array}$ & $\begin{array}{l}\text { Mar } \\
2016\end{array}$ \\
\hline $2016-14$ & $\begin{array}{l}\text { Peter CARROLL, } \\
\text { Gregory BOUNDS and } \\
\text { Rex DEIGHTON-SMITH }\end{array}$ & $\begin{array}{l}\text { Towards Responsive Regulations and } \\
\text { Regulatory Coherence in ASEAN and } \\
\text { East Asia: The Case of Australia }\end{array}$ & $\begin{array}{c}\text { Mar } \\
2016\end{array}$ \\
\hline $2016-13$ & Derek GILL & $\begin{array}{l}\text { Defining Regulatory Management } \\
\text { System }\end{array}$ & $\begin{array}{l}\text { Mar } \\
2016\end{array}$ \\
\hline $2016-12$ & Derek GILL & $\begin{array}{l}\text { Regulatory Coherence: The Case of } \\
\text { New Zealand }\end{array}$ & $\begin{array}{l}\text { Mar } \\
2016\end{array}$ \\
\hline $2016-11$ & $\begin{array}{l}\text { Sang-Hyop LEE, Jungsuk } \\
\text { KIM and Donghyun } \\
\text { PARK }\end{array}$ & $\begin{array}{l}\text { Demographic Change and Fiscal } \\
\text { Sustainability in Asia }\end{array}$ & $\begin{array}{c}\text { Mar } \\
2016\end{array}$ \\
\hline $2016-10$ & $\begin{array}{l}\text { Ayako OBASHI and } \\
\text { Fukunari KIMURA }\end{array}$ & $\begin{array}{l}\text { The Role of China, Japan, and Korea } \\
\text { in Machinery Production Networks }\end{array}$ & $\begin{array}{l}\text { Mar } \\
2016\end{array}$ \\
\hline 2016-09 & $\begin{array}{l}\text { Ayako OBASHI and } \\
\text { Fukunari KIMURA }\end{array}$ & $\begin{array}{l}\text { Deepening and Widening Production } \\
\text { Networks in ASEAN }\end{array}$ & $\begin{array}{l}\text { Mar } \\
2016\end{array}$ \\
\hline 2016-08 & Willem THORBECKE & $\begin{array}{l}\text { Increasing the Resilience of Asian } \\
\text { Supply Chains to Natural Disasters: } \\
\text { The Role of the Financial Sector }\end{array}$ & $\begin{array}{c}\text { Feb } \\
2016\end{array}$ \\
\hline $2016-07$ & $\begin{array}{l}\text { Hiroyuki NAKATA, } \\
\text { Yasuyuki SAWADA and } \\
\text { Kunio SEKIGUCHI }\end{array}$ & $\begin{array}{l}\text { Market Concentration and Risk- } \\
\text { Prevention Incentives: The Case of the } \\
\text { Hard Disk Drive Industry }\end{array}$ & $\begin{array}{c}\text { Feb } \\
2016\end{array}$ \\
\hline 2016-06 & Meinhard BREILING & $\begin{array}{l}\text { Tourism Supply Chains and Natural } \\
\text { Disasters: The Vulnerability Challenge } \\
\text { and Business Continuity Models for } \\
\text { ASEAN Countries }\end{array}$ & $\begin{array}{c}\text { Feb } \\
2016\end{array}$ \\
\hline
\end{tabular}




\begin{tabular}{|c|c|c|c|}
\hline No. & Author(s) & Title & Year \\
\hline $2016-05$ & $\begin{array}{l}\text { Masaru TANAKA and } \\
\text { Shigeatsu } \\
\text { HATAKEYAMA }\end{array}$ & $\begin{array}{l}\text { Towards Reframing the Spirit of } \\
\text { ASEAN Environmentalism: Insights } \\
\text { from Japan's COHHO Experience and } \\
\text { Studies }\end{array}$ & $\begin{array}{l}\text { Feb } \\
2016\end{array}$ \\
\hline 2016-04 & Manaek SM PASARIBU & $\begin{array}{l}\text { Challenges of Indonesian } \\
\text { Competition Law and Some } \\
\text { Suggestions for Improvement }\end{array}$ & $\begin{array}{c}\text { Jan } \\
2016\end{array}$ \\
\hline 2016-03 & $\begin{array}{l}\text { VO Tri Thanh and } \\
\text { NGUYEN Anh Duong }\end{array}$ & $\begin{array}{l}\text { Promoting Rural Development, } \\
\text { Employment, and Inclusive Growth } \\
\text { in ASEAN }\end{array}$ & $\begin{array}{c}\text { Jan } \\
2016\end{array}$ \\
\hline 2016-02 & $\begin{array}{l}\text { Venkatachalam } \\
\text { ANBUMOZHI }\end{array}$ & $\begin{array}{l}\text { Convergence of Opportunities: } \\
\text { Resilience and the ASEAN } \\
\text { Community }\end{array}$ & $\begin{array}{c}\text { Jan } \\
2016\end{array}$ \\
\hline 2016-01 & $\begin{array}{l}\text { Lili Yan ING, Shujiro } \\
\text { URATA and Yoshifumi } \\
\text { FUKUNAGA }\end{array}$ & $\begin{array}{l}\text { How Do Exports and Imports Affect } \\
\text { the Use of Free Trade Agreements? } \\
\text { Firm-level Survey Evidence from } \\
\text { Southeast Asia }\end{array}$ & $\begin{array}{c}\text { Jan } \\
2016\end{array}$ \\
\hline
\end{tabular}

Previous year of ERIA Discussion Paper, can be downloaded at:

http://www.eria.org/publications/discussion papers/FY2015/

http://www.eria.org/publications/discussion_papers/FY2014/

http://www.eria.org/publications/discussion_papers/FY2013/

http://www.eria.org/publications/discussion_papers/FY2012/

http://www.eria.org/publications/discussion_papers/FY2011/

http://www.eria.org/publications/discussion_papers/FY2010/

http://www.eria.org/publications/discussion_papers/FY2009/

http://www.eria.org/publications/discussion papers/FY2008/ 